\title{
Systems-level analysis of age-related macular degeneration reveals global biomarkers and phenotype-specific functional networks
}

\author{
Aaron M Newman ${ }^{1,5}$, Natasha B Gallo1, Lisa S Hancox², Norma J Miller³, Carolyn M Radeke ${ }^{1}$, Michelle A Maloney ${ }^{1}$,
} James B Cooper ${ }^{4}$, Gregory S Hageman ${ }^{3}$, Don H Anderson ${ }^{1}$, Lincoln V Johnson ${ }^{1}$ and Monte J Radeke ${ }^{\text {* }^{*}}$

\begin{abstract}
Background: Age-related macular degeneration (AMD) is a leading cause of blindness that affects the central region of the retinal pigmented epithelium (RPE), choroid, and neural retina. Initially characterized by an accumulation of sub-RPE deposits, AMD leads to progressive retinal degeneration, and in advanced cases, irreversible vision loss. Although genetic analysis, animal models, and cell culture systems have yielded important insights into AMD, the molecular pathways underlying AMD's onset and progression remain poorly delineated. We sought to better understand the molecular underpinnings of this devastating disease by performing the first comparative transcriptome analysis of AMD and normal human donor eyes.

Methods: RPE-choroid and retina tissue samples were obtained from a common cohort of 31 normal, 26 AMD, and 11 potential pre-AMD human donor eyes. Transcriptome profiles were generated for macular and extramacular regions, and statistical and bioinformatic methods were employed to identify disease-associated gene signatures and functionally enriched protein association networks. Selected genes of high significance were validated using an independent donor cohort.
\end{abstract}

Results: We identified over 50 annotated genes enriched in cell-mediated immune responses that are globally over-expressed in RPE-choroid AMD phenotypes. Using a machine learning model and a second donor cohort, we show that the top 20 global genes are predictive of AMD clinical diagnosis. We also discovered functionally enriched gene sets in the RPE-choroid that delineate the advanced AMD phenotypes, neovascular AMD and geographic atrophy. Moreover, we identified a graded increase of transcript levels in the retina related to wound response, complement cascade, and neurogenesis that strongly correlates with decreased levels of phototransduction transcripts and increased AMD severity. Based on our findings, we assembled protein-protein interactomes that highlight functional networks likely to be involved in AMD pathogenesis.

Conclusions: We discovered new global biomarkers and gene expression signatures of AMD. These results are consistent with a model whereby cell-based inflammatory responses represent a central feature of AMD etiology, and depending on genetics, environment, or stochastic factors, may give rise to the advanced AMD phenotypes characterized by angiogenesis and/or cell death. Genes regulating these immunological activities, along with numerous other genes identified here, represent promising new targets for AMD-directed therapeutics and diagnostics.

Please see related commentary: http://www.biomedcentral.com/1741-7015/10/21/abstract

\footnotetext{
* Correspondence: monte.radeke@lifesci.ucsb.edu

${ }^{1}$ Center for the Study of Macular Degeneration, Neuroscience Research Institute, Biological Sciences 2 Building, University of California, Santa

Barbara, CA 93106-5060, USA

Full list of author information is available at the end of the article
} 


\section{Background}

The neural retina, retinal pigmented epithelium (RPE), and choroid tissue complex is one of the most physiologically active tissues in humans and arguably our most important sensory organ [1]. Perhaps due to its high metabolic rate, unique vasculature system, and focused exposure to light, this tissue complex, and in particular the central macular region, is predisposed to degeneration $[2,3]$. The age-related form of macular degeneration (AMD) is the leading cause of irreversible blindness in developed countries, and it is now estimated that $6.5 \%$ of the US population, aged 40 years and older, have AMD [4]. The most common AMD phenotype, generally termed 'dry AMD', is characterized by an increase in the number and diameter of extracellular sub-RPE deposits called drusen, pigmentary irregularities, progressive atrophy of the RPE and retina, and a graded loss in visual acuity [5-10]. In advanced cases, AMD is often associated with sub-retinal choroidal neovascularization (CNV; or 'wet AMD') and/or a clearly demarcated area of geographic atrophy (GA) in the macular region of the RPE. Both advanced AMD phenotypes cause severe vision loss.

Although aging is the prevailing risk factor for AMD, environmental factors such as smoking or oxidative stress may contribute to AMD's occurrence and/or progression [11-14]. Moreover, genetic linkage analysis and genome-wide association studies have identified a number of important genetic risk factors in recent years. The discovery of genetic variants in complement factor $\mathrm{H}$, for example, firmly established a link between the complement cascade and AMD biology [15-18]. Other studies identified AMD risk variants in additional complement-related genes (for example, C2, CFB, CFHR1/3, C3) [19-22] as well as in a variety of non-complementrelated genes, including a locus of unknown functional relevance (for example, ARMS2/HTRA1) [23-26] and loci related to lipid metabolism ( $A P O E, L I P C, A B C A 1$ ) [27-33]. Despite these important discoveries, a detailed view of the biological pathways that mediate AMD development and progression has remained obscure. Furthermore, due to the morphological diversity of AMD clinical phenotypes, whether AMD represents a single disease consisting of multiple phenotypes or a disorder composed of distinct macular diseases (for example, dry AMD, CNV, and GA) is still unclear.

Compared to previous studies of AMD that have relied upon indirect experimental systems (for example, animal models, cell culture systems) and a reductionist experimental approach, gene expression profiling of human ocular tissues has great potential to more accurately and comprehensively resolve AMD-associated molecular signaling pathways. Coupled with a systems biology analysis, transcriptome profiling can be used for the unbiased identification of gene co-expression modules, to build molecular models with predictive utility, and to elucidate functional networks $[34,35]$. Although several groups have completed transcriptome-wide studies of relevance to AMD, including the identification of macular and extramacular differences in RPE-choroid gene expression, RPE-specific expression signatures, and AMD-associated changes in circulating leukocytes [36-40], no direct transcriptome-wide analysis of human RPE-choroid and retina AMD tissues has been reported to date.

Here we present our findings from a comparative transcriptome analysis of ocular tissues derived from 68 human donor eyes, including 26 well-characterized AMD eyes and 11 potential pre-AMD eyes. Our study identifies cell-mediated immune responses as the central feature of all AMD phenotypes, thus supporting the hypothesis that AMD is a single disease with a common immunological core process. In addition, in the RPE-choroid, we identified transcripts related to apoptosis and angiogenesis that are over-expressed in GA and wet AMD, respectively. In the retina, we observed a graded over-expression of wound response, complement, and neurogenesis genes that correlates with reduced levels of phototransduction transcripts and increasingly advanced AMD phenotypes. Finally, using these functionally enriched expression signatures, we assembled two detailed interactomes that highlight modular functional networks of classical dry AMD, $\mathrm{CNV}$, and GA in RPE-choroid and neural retina tissues. These data provide new insights into the expression landscape of AMD pathophysiology, and reveal numerous new targets for the development of AMD-directed pharmaceuticals and diagnostics.

\section{Methods}

\section{Donor eye tissue and RNA purification}

RPE-choroid and retinal samples were isolated from human donor eyes obtained from the University of Iowa (GSH) and the Lions Eye Bank of Oregon. The Iowa eyes were selected from a well-characterized repository derived from over 3, 900 donors. Medical and ophthalmic histories, a family questionnaire, blood, and sera were obtained from the majority of donors. All Iowa donors were independently classified by two retinal specialists using gross pathologic features, and for 63 of the 68 Iowa donors, fundus photographs were utilized for grading purposes using well-established methods and morphological criteria $[5,41,42]$. The combined analysis of the retinal specialists was adjudicated (GSH) and donors were placed into groups based on the morphological phenotype of the eye with the most advanced pathology. Table 1 provides details of the grading scheme, and cross-references our groupings with the AREDS and Rotterdam grades, where 
Table 1 AMD classification scheme

\begin{tabular}{|c|c|c|c|c|c|}
\hline $\begin{array}{l}\text { AMD } \\
\text { classification }\end{array}$ & $\begin{array}{l}\text { Alternative } \\
\text { name }\end{array}$ & $\begin{array}{c}\text { AREDS } \\
\text { level [42] }\end{array}$ & $\begin{array}{l}\text { Rotterdam } \\
\text { grade [41] }\end{array}$ & Description & $\begin{array}{l}\text { Donors per } \\
\text { class }^{\mathrm{a}}\end{array}$ \\
\hline Normal & & 1 & Oa & No features of AMD & 31 \\
\hline MD1 & Pre-AMD & 1 & $0 \mathrm{~b}$ & Hard macular drusen $(<63 \mu \mathrm{m})$ only & 7 \\
\hline \multirow[t]{2}{*}{ MD2 } & $\begin{array}{l}\text { Sub-clinical } \\
\text { pre-AMD }\end{array}$ & 2 & $1 a$ & Soft, distinct macular drusen (> $63 \mu \mathrm{m})$ & 4 (1a only) \\
\hline & & & $1 b$ & Macular pigmentary irregularities without soft drusen & \\
\hline \multirow[t]{3}{*}{ Dry AMD } & $\begin{array}{l}\text { Dry AMD } \\
\text { (non-GA) }\end{array}$ & $3,4 b$ & $2 a$ & Soft, indistinct $(>125 \mu \mathrm{m})$ or reticular macular drusen & 17 \\
\hline & & & $2 \mathrm{~b}$ & Soft distinct macular drusen (> $63 \mu \mathrm{m})$ with pigmentary changes & 17 \\
\hline & & & 3 & Soft indistinct macular drusen with pigmentary changes & 17 \\
\hline GA & $\begin{array}{l}\text { Geographic } \\
\text { atrophy }\end{array}$ & $4 a$ & 4 & $\begin{array}{l}\text { Sharply demarcated area of apparent absence of the RPE (> } 175 \mu \mathrm{m}) \\
\text { involving central macular region }\end{array}$ & 2 \\
\hline CNV & Wet AMD & $4 a$ & 4 & Sub-retinal choroidal neovascularization & 4 \\
\hline GA/CNV & & $4 a$ & 4 & Geographic atrophy with choroidal neovascularization & 3 \\
\hline
\end{tabular}

${ }^{a}$ Number of lowa cohort donors per AMD classification group.

visual impairment plays an additional role in classification. For each donor, only the eye with the most advanced phenotype (that is, the eye on which the classification was based) was used for transcriptome analysis. Macular trephine punches $(8 \mathrm{~mm})$ and temporally adjacent extramacular trephine punches $(6 \mathrm{~mm})$ of the RPE-choroid and retina were collected from Iowa eyes within 4 hours of postmortem, flash frozen in liquid $\mathrm{N}_{2}$, and stored at $-80^{\circ} \mathrm{C}$. Total DNA-free RNA was purified using a Qiagen RNeasy miniprep and on-column DNA digestion according to the methods of the manufacturer (Qiagen, Inc., Valencia, CA, USA). The RPE-choroid isolation procedures and RNA purification methods for material originating from the Lions Eye Bank of Oregon are described in Radeke et al. [36]. No retina samples were acquired from the Oregon eyes. Unlike Iowa eyes, postmortem times for Oregon eyes ranged up to 8.7 hours $(90 \%>4$ hours), whole Oregon eyes were stored in RNA stabilization buffer (RNAlater, Ambion, Inc., Austin, TX, USA) at $4^{\circ} \mathrm{C}$ prior to sample collection, and off-column DNA digestion was used. In addition, unlike the Iowa eyes, which were expertly graded, the Oregon eyes received only a general classification of AMD based on medical histories confirmed by ophthalmological records. Oregon eyes with an absence of AMD clinical history were considered normal. Since Oregon eyes received a less rigorous AMD classification than Iowa eyes, the Oregon cohort was reserved for validation purposes only. Donor specific details (for example, age, gender, and AMD phenotype) can be accessed through the Gene Expression Omnibus [GEO:GSE29801].

This study was reviewed and approved by the institutional review boards at St Louis University, the University of Iowa, the University of Utah, and the University of California, Santa Barbara and conforms to the tenets of the Declaration of Helsinki. Written informed consent was obtained from all participants or surviving relatives.

\section{Microarray hybridization, quantification, and normalization}

Global transcriptome profiling was carried out using the Agilent Whole Human Genome $4 \times 44 \mathrm{~K}$ in situ oligonucleotide array platform (G4112F, Agilent Technologies, Inc., Santa Clara, CA, USA) using the reagents and methods of the manufacturer, with the exception that 'spike-in' controls were not used. For the tissue samples, a twocolor universal reference experimental design was employed where the dyes used to label experimental and reference samples were alternated with each sample. The universal reference was derived from a pool of donor eyes and consisted of a 50:50 mixture of RPE-choroid and retina RNA purified from tissue remaining after the macular and extramacular punches were removed. After Lowess correction, background subtraction, and normalization using the reference RNA, the net intensity was expressed as a percentage of the sum of all signals times 100, 000 (Percentage of total $\times 100,000$ ). Detailed DNA microarray methods and microarray data associated with this publication are available through the Gene Expression Omnibus [GEO:GSE29801].

\section{Identification of contaminating genes}

To improve data quality and overall signal-to-noise ratio, RPE-choroid and retina gene expression datasets were filtered for the following putative contaminants: retinaenriched genes in the RPE-choroid, RPE-choroid-enriched genes in the retina, and gender-specific genes (for example, XIST). Differentially expressed genes were determined using an unpaired, two-sided Student's $t$-test with unequal variance, and the resulting $P$-values were adjusted by permuting class labels 1, 000 times with the Fisher-Yates method [43]. Moreover, a false discovery rate (also, q-value or $Q$ ) was determined for each gene probe using the method of Storey and Tibshirani [44]. Unfiltered 
RPE-choroid and retina microarray datasets were combined, quantile normalized [45], and $\log _{2}$ adjusted, and differentially expressed genes between RPE-choroid and retina with $Q \leq 0.02$, permuted $P \leq 0.01$, and fold change $\geq 1.5$ were identified (Figure S1 in Additional file 1). Of 7, 029 RPE-choroid-enriched and 7, 736 retina-enriched gene probes meeting these statistical criteria, those with mean expression levels of $<100$ (that is, approximately 6.64 in $\log _{2}$ space) in the opposing dataset were flagged as contaminants. Genes with gender-specific expression differences were identified using the combined RPE-choroid and retina dataset, and all genes with $Q \leq 0.0001$, permuted $P \leq 0.001$, and fold change $\geq 1.5$ were flagged as gender-specific contaminants (21 male-enriched and 11 female-enriched gene probes).

\section{Combinatorial class comparisons for disease gene identification}

Unfiltered RPE-choroid and retina datasets were quantile normalized separately and $\log _{2}$ transformed. Gene probes flagged as contaminants, or with minimal differential expression across all arrays (sample variance $\leq 5$ ), were excluded from further analysis. Donor samples diagnosed as GA/CNV $(n=3)$ were combined with the pure GA $(n=2)$ and $\operatorname{CNV}(n=4)$ samples to increase the $n$ in these categories. In addition, samples collected from one 43-year-old individual diagnosed with AMD were excluded due to an atypically early disease onset. After data preprocessing, all AMD/pre-AMD phenotypes (preAMD (MD1), sub-clinical pre-AMD (MD2), MD1 + MD2 (MD), Dry AMD, GA, CNV), both separately and combined (global), were tested for significant differential expression against macular and/or extramacular agematched normal donor samples ( $\geq 60$ years), for a total of 21 two-class comparisons per gene probe per microarray dataset (RPE-choroid and retina). Statistical methods for differential expression analysis are described in 'Identification of contaminating genes'. A table of all gene probes with a permuted $P<0.1$ and fold change $\geq 1.5$ is provided as Table $\mathrm{S} 1$ in Additional file 2.

\section{Identification of AMD disease modules}

Differentially expressed genes (listed in Table S1 in Additional file 2) were organized into a matrix consisting of the $P$-value for each gene (row $i$ ) and class comparison (column $j$ ). Each $P$-value was converted into a significance score $S_{i j}$, calculated as $-\log _{10}\left(P_{i j}\right)$, and all scores were assigned directionality based on the up- or downregulation of each disease gene (positive or negative, respectively; non-significant genes have $S=0$ ). Gene probes representing the same gene were collapsed by averaging significance scores, resulting in a matrix consisting of 42 columns ( 21 comparisons $\times 2$ tissue types) and 6,479 rows (unique genes/probes). The matrix was adjusted for AutoSOME clustering [46] using unit variance normalization (columns) and sum of squares $=1$ normalization (rows and columns). All rows were subsequently clustered with AutoSOME using 500 ensemble runs, $P<0.005$, and otherwise default parameters [46]. For each tissue type, clusters with genes primarily overor under-expressed in the same phenotype were combined into larger groups termed 'disease modules'.

\section{Immunoglobulin gene probes}

In one disease module (RPE-choroid Global Up), we observed a number of immunoglobulin-related gene probes along with many unannotated probes with highly similar expression profiles. Using AutoSOME [46], all gene probes with similar co-expression patterns to known IG probes were identified by clustering the expression data from the Global Up module (cluster parameters: $P<0.05,500$ ensemble runs, and otherwise default parameters). BLAT searches of the human genome reference sequence using the UCSC Genome Web Browser confirmed probe homology to IGJ, as well as immunoglobulin heavy, kappa, and lambda chain sequences. In total, 31 IG probes were found, and their expression values were averaged in three figures to conserve space. The 31 individual probes are highlighted in Figure S7 in Additional file 1.

\section{Disease state prediction}

To validate candidate AMD biomarkers, we used the GenePattern implementation of support vector machine (SVM) [47], a machine learning algorithm for sample classification and prediction based on complex pattern recognition. Iowa expression data were $\log _{2}$ transformed and median-centered for the twenty most significant genes from the RPE-choroid Global Up module. Using known donor classifications (that is, Normal versus AMD/pre-AMD), the expression data, with and without age, were split into three training and test groups for stratified three-fold cross-validation (SplitDatasetTrainTest: split method $=$ cross-validation; folds $=3$; otherwise default parameters). SVM models were built for the training data (using GenePattern default parameters), and run on the corresponding test datasets, the full Oregon dataset (expression data processed identically to Iowa set), and a negative control consisting of randomized Oregon data (20 random genes with and without scrambled ages). Cross-validation accuracy was computed as the total number of correct classifications from all three Iowa test datasets divided by the number of Iowa RPE-choroid array samples $(n=126)$. SVM classification accuracy for the validation cohort (Oregon data) was calculated as the average accuracy obtained using the three SVM models. To calculate the statistical significance for overall classifier performance on each dataset, 
results from each of the three models were randomized by permuting class labels 10 million times, and a $P$-value was determined as the fraction of randomized results with a classification accuracy (averaged over the three models) equal to or exceeding the original non-randomized classification results [48]. P-values were also determined for individual SVM models using the same approach without averaging classification results. Finally, we note that our selection of the top $20 \mathrm{RPE}$-choroid Global Up genes for this analysis was not arbitrary, but was determined by iteratively running SVM (using crossvalidation) on all consecutive subsets of RPE-choroid Global Up genes in the Iowa dataset, from the top singleton gene, to the top two genes, to the top three genes, and so forth. Using gene expression data alone, the highest classification accuracy was achieved using the top 20 and 21 genes (identical results; data not shown).

\section{Identification of disease modules enriched in protein- protein associations}

Each disease module was analyzed for statistical enrichment of protein-protein associations using the STRING v8.3 database [49] (default parameters). Importantly, genes in GA\&CNV Up/Down modules were not analyzed independently, but were included in GA and CNV Up/ Down modules. Since STRING does not estimate statistical significance, as a proxy for enrichment, we used the average node degree $D$, defined as $2 \times$ Number of edges/ Number of nodes (edges $=$ interactions; nodes $=$ proteins). Monte Carlo sampling was employed to estimate the null distribution of $D$ by sampling $50,100,200,300$, and 400 randomly drawn proteins 10, 000 times from the STRING database. Regression analysis revealed perfect linear trends for expected node degree $E(D)$ for $P=0.05$ $\left(\mathrm{R}^{2}=1 ; E(D)=0.0023 \times\right.$ nodes +0.7318$)$ and $P=0.01$ $\left(\mathrm{R}^{2}=1 ; E(D)=0.0022 \times\right.$ nodes +0.9068$)$, and for each $P$ value we determined $E(D)$ given the actual number of nodes within each disease module (that is, genes with matching proteins in STRING). Figure S11 in Additional file 1 illustrates the results of this analysis for the RPEchoroid (Figure S11a) and retina (Figure S11b), expressed as the deviation in node degree from random chance.

\section{Assembly of RPE-choroid and retina AMD interactomes}

To construct high-quality AMD interactomes, we integrated both direct and indirect protein-protein interaction (PPI) data from three sources: Ingenuity Pathway Analyzer (IPA; Ingenuity Systems, Inc., Redwood City, CA, USA), STRING v8.3 [49], and a curated human PPI dataset [50]. Redundant protein-protein associations were eliminated in the final interactomes according to the following dominance series: Bossi and Lehner PPI > IPA > STRING database/experiment evidence > STRING text-mining evidence. Thus, Bossi and Lehner PPI data were given precedence over all other PPI data sources.

\section{RPE-choroid interactome}

Three RPE-choroid disease modules (Global Up, CNV Up, and GA Up) were found to have significant enrichment in protein-protein associations $(P<0.01$; Figure $S 11$ in Additional file 1). We note that CNV Up and GA Up modules include genes from the RPE-choroid GA\&CNV Up module. Using at most 70 nodes and only interactions derived from Homo sapiens, an IPA Core Analysis was run for each of the three disease modules. For inclusion in the RPE-choroid interactome, we restricted IPA results to the highest scoring IPA network for a given Core Analysis. We also required a low ratio of predicted to observed proteins/complexes. Using these criteria, Global Up and CNV Up modules achieved high-quality networks. To reduce IPA network complexity and thus improve human readability, we eliminated self-edges as well as predicted proteins unnecessary for linking disease module gene products into the network. Additional interactions for each disease module were determined using STRING, with a minimum score of 0.7 ('high confidence' score). Since RPE-choroid GA Up is prominently enriched in apoptosis, all STRING interactions among RPE-choroid GA Up genes found in the 'apoptosis' Gene Ontology category (determined using ToppFun [51]) were added. Additional interactions among CNV Up proteins were also added by assembling a gene set consisting of CNV Up genes found in the IPA network along with additional CNV Up genes associated with the 'Wnt signaling pathway' and 'extracellular matrix' functional enrichment categories (determined with DAVID [52]). STRING interactions among CNV Up gene products derived from experimental or database evidence (score $\geq 0.7$ ) were preferentially added; however, interactions derived from STRING text-mining (text score $\geq 0.7$ ) were also added to incorporate one remaining protein, FGF9. Given the abundance of interactions identified by IPA for Global Up, no STRING interactions were added to the Global Up subnetwork. Finally, interactions among all three disease modules from the PPI dataset of Bossi and Lehner [50] were added. The final RPE-choroid interactome was rendered using Cytoscape 2.8.0 [53].

\section{Retina interactome}

Two retina disease modules, Global Up and CNV Up, were found to be significantly enriched in protein associations $(P<0.01$; Figure S11 in Additional file 1$)$. Given the enrichment of retina CNV Down in phototransduction processes and the critical importance of phototransduction to a perceptible disease phenotype, we also analyzed retina CNV Down genes for inclusion in the retina interactome. Notably, CNV Up and CNV Down modules include genes from the retina GA\&CNV Up and 
Down modules, respectively. Using the same network quality criteria as used for the RPE-choroid, the IPA Core Analysis did not yield high quality networks for any of the three retina disease modules. Next, we used STRING to identify protein-protein associations. Given the large numbers of genes in retina CNV Up and Down modules, we first isolated subsets of functionally enriched genes from both modules using ToppFun [51]. Since CNV Up is predominantly enriched in neural-related processes, we isolated CNV Up genes found in the following Gene Ontology categories: neurogenesis, generation of neurons, neuron differentiation, and transmission of nerve impulse. CNV Down genes associated with vision were also isolated using the Gene Ontology categories: sensory perception of light stimulus, phototransduction, and response to light stimulus. We included all STRING interactions found within a combined gene set consisting of all Global Up genes, neurogenesis-related genes from CNV Up and vision-related genes from $\mathrm{CNV}$ Down (we employed the default STRING score of 0.4 since a score of 0.7 resulted in $30 \%$ fewer connected proteins). Finally, we added all human PPI data [50] determined for genes in the STRING-derived interactome. The final retina interactome was rendered with Cytoscape 2.8.0 [53].

\section{Compilation of AMD-associated genes}

Through an extensive PubMed search and survey of recent review articles, we assembled a large list of genes or gene products with a confirmed or putative association with AMD resulting from genetic linkage, expression differences (RNA or protein) or localization to drusen in humans [15-33,40,54-110]. The gene list is provided in Table S2 in Additional file 3. Rather than requiring validation in two or more studies, only a single reference of association was required for inclusion in this list, to allow for a more comprehensive collection. Fisher's exact test was used to calculate the significance of overlap between the 283 AMD-associated genes (HLA super-locus excluded from count) in Table S2 in Additional file 3 and the RPE-choroid and retina interactomes (83 and 92 total differentially expressed network elements, respectively); only annotated genes from the Agilent $4 \times 44 \mathrm{k}$ chipset were considered for the total population count $(n=19$, 542).

\section{Results}

\section{AMD transcriptome profiling}

To investigate gene expression programs that characterize AMD, we assembled global transcriptome profiles of macular and extramacular RPE-choroid and neural retina tissues from normal and AMD human donor eyes. Of two donor cohorts examined in this study, the Iowa cohort consisted of 31 normal eyes and 37 atypical eyes organized into the following graded phenotypes: macular hard drusen (MD1), distinct macular soft drusen 65 to $125 \mu \mathrm{m}$ without pigmentary abnormalities (MD2), dry AMD without geographic atrophy (Dry AMD), wet AMD (CNV), and dry AMD with geographic atrophy (GA) (see Table 1 for detailed phenotype descriptions). The latter three classes correspond to clinically recognized AMD phenotypes while the former two classes, MD1 and MD2, represent potential pre- or sub-clinical stages of AMD. Although occasional hard drusen are common in the adult population, elevated numbers of hard drusen, and in particular macular hard drusen (that is, MD1), are not common and have been associated with an increased risk for developing AMD [111-114]. In addition, morphological features of MD2 are classically associated with AMD, but have not yet reached the size or extent necessary for a clinical diagnosis. These two phenotypes were therefore included in this study to explore potentially early events leading to the development of clinical AMD. Unlike Iowa eyes, donors from the second cohort were reserved for validation purposes (Oregon eyes, $n=30$, RPE-choroid only). As a measure of quality control, we evaluated samples from both cohorts for postmortem RNA degradation, inter-array concordance, and agreement with previously published transcriptome experiments [36,38,115-117], and found our data to be of high quality and suitable for genomics analysis (see Additional file 4 for a detailed discussion of sample and array quality control measures).

Employing an exhaustive series of pairwise class comparisons between age-matched normal donor samples $(\geq$ 60 years) and the five graded AMD/pre-AMD phenotypes from the Iowa cohort, we identified numerous candidate AMD-associated genes, all of which satisfy a minimum fold change of 1.5 and permuted $P$-value cutoff of 0.1 (Table S1 in Additional file 2). Using a false discovery rate of $10 \%$ to account for multiple hypothesis testing (that is, $Q \leq 0.1$ ), we found seven genes in the RPE-choroid that exhibit differential expression across all AMD phenotypes, regardless of macular or extramacular origin. Six of these genes are expressed at higher levels in AMD (Figure 1), including two genes (CXCL1O and CXCL9) that encode angiostatic chemokines involved in leukocyte recruitment and implicated in diverse pathologies [118]. Additional genes found at higher levels include chromosome 10 open reading frame 18 (C10orf18), ADP-ribosylation factor-like 9 (ARL9; inferred from unannotated probe A_23_P58137, see Figure S5 in Additional file 1 for evidence), frizzled homolog 10 (FZD10), and cathepsin L2 (CTSL2). Only one gene was found consistently expressed at lower levels in the AMD RPE-choroid (gene probe A_24_P925565). We also found four globally differentially expressed genes 


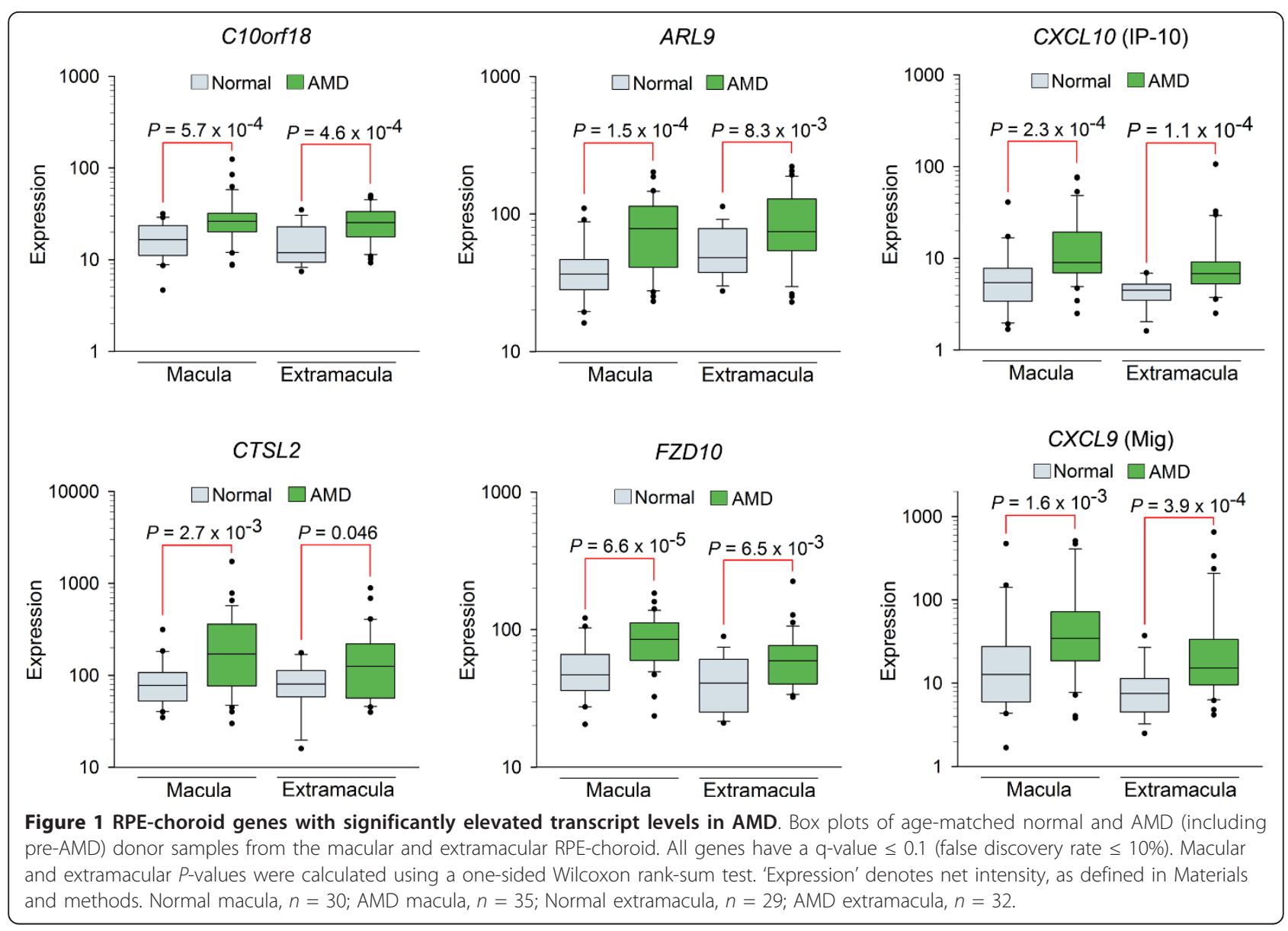

between diseased and normal samples in the retina for $Q \leq$ 0.1 (three genes of increased abundance, LOC100294179, $H L A-A$, and ITGB1BP2, and one gene with lesser abundance, GSTT1). Furthermore, using $Q \leq 0.1$, most of the gene expression changes associated with specific AMD phenotypes were found in the sub-clinical AMD state (that is, MD2), and for some disease phenotypes, no genes showed differential expression (for example, CNV in RPEchoroid).

\section{Identification of AMD disease modules}

Transcriptional heterogeneity in human donor eye tissue can arise from multiple factors, including normal genetic variation, environmental influences unrelated to AMD, the presence of mixed cell types, and/or variable degrees of AMD progression. Hence, the small number of candidate disease genes identified using $Q \leq 0.1$ was not unexpected. As an alternative approach, we relaxed the differential expression threshold for individual genes, and focused on identifying gene groups that exhibit both coordinated expression in specific disease phenotypes and significant functional enrichment in one or more biological processes. In particular, the q-value threshold was eliminated, and all differentially expressed genes identified in the class comparison with permuted $P<0.1$ (Table S1 in Additional file 2) were clustered based on significance scores using AutoSOME [46]. Resulting clusters were then analyzed for functional enrichments. This approach, inspired by Segal et al. [119], allows for the determination of gene expression programs that may be obscured by noise. All clustering results are illustrated in Figure S6 in Additional file 1 and the corresponding gene lists and data are provided in Table S3 in Additional file 5. To highlight modularity, clusters with genes differentially expressed in the same disease phenotype(s) were further combined into AMD disease modules, for both RPE-choroid (Figure 2a, left) and retina (Figure $2 \mathrm{~b}$, left).

\section{Elevated cellular immune response is associated with all} disease phenotypes

Although most of the 32 identified disease modules are restricted to discrete AMD phenotypes (Figure 2, left), four global disease modules were identified that consist of genes differentially expressed in multiple AMD and pre-AMD phenotypes (Figure 2a, b, right panels; also 


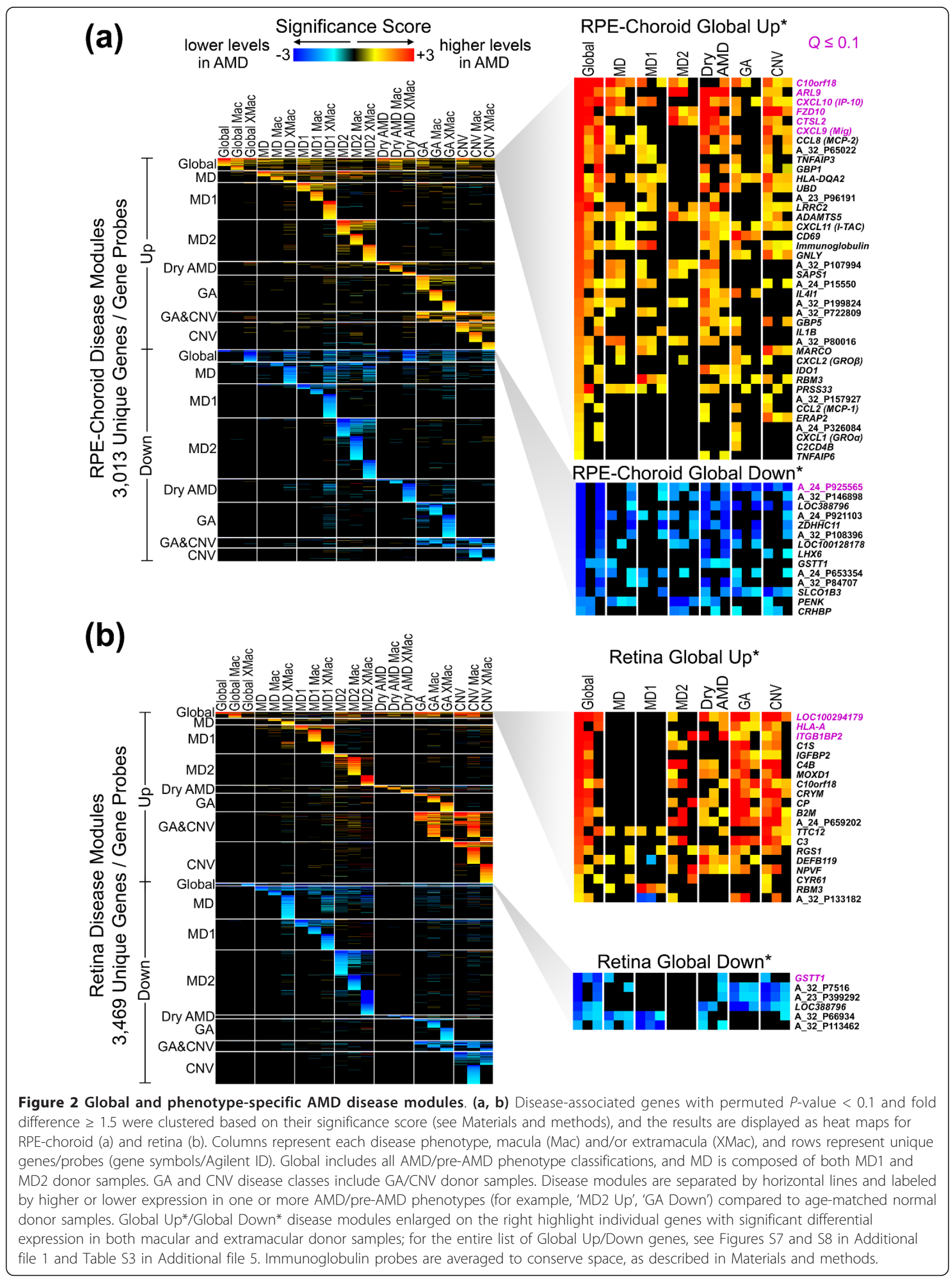


see Figures S7 and S8 in Additional file 1). Among the more than 50 array probes corresponding to annotated genes in the RPE-choroid Global Up module, Gene Ontology analysis revealed a striking enrichment in genes regulating cell-mediated immune processes (for example, chemokine activity, $P=3.0 \times 10^{-11}$; Table S4 in Additional file 6). This module includes genes for all known CXCR3 ligands (the previously identified CXCL9 and CXCL10 shown in Figure 1, along with CXCL11); $C C L 2$, which encodes a pro-inflammatory chemokine previously associated with AMD [64]; CD1D and CD86, which are both associated with antigen presenting cells [6,120,121]; and immunoglobulins (IGJ, IGH@, IGK@, IGL@). Similarly, the Retina Global Up module is significantly enriched in inflammatory genes $\left(P=1.3 \times 10^{-4}\right)$. However, unlike the RPE-choroid Global Up module, these genes are involved in the complement and coagulation cascades (C3, C4B, C1S, CFI, F5, SERPINA5; Table S4 in Additional file 6). In contrast to Global Up genes, Global Down genes are not functionally enriched, aside from three neurofilament-associated genes in the retina (NEFL, NEFM, PRPH), suggesting that AMD is associated with a general down-regulation of genes involved in diverse cellular processes. Notably, one gene present in both RPE-choroid and Retina Global Down modules, GSTT1 (glutathione S-transferase theta 1), is known to play a protective role in RPE oxidative stress, and reduced levels of this gene may be associated with both advanced RPE aging [122] and AMD [85]. In summary, by examining clusters of co-expressed genes for functional enrichment, these results greatly expand upon the global disease genes previously identified using $Q \leq 0.1$ (Figure 1), and indicate that there are multiple biomarkers of AMD. Furthermore, these data are consistent with a global cellular immune response in AMD pathogenesis.

\section{Validation of RPE-choroid global signature genes using an independent cohort}

To validate our finding of a global AMD expression signature, we used a SVM [47] classifier applied to the macular and extramacular expression profiles from the top 20 genes in the RPE-choroid Global Up disease module (Figure 3a). In addition to the set of donor samples used in our initial transcriptome analysis (Iowa set), we analyzed a validation cohort of RPE-choroid samples collected from both normal eyes and eyes with a clinical diagnosis of AMD obtained from the Lions Eye Bank of Oregon. Using stratified three-fold cross-validation, we trained SVM models on three different subsets of Iowa RPE-choroid samples, and evaluated each model on the remaining Iowa samples not used for training (one unique test set for each model, $n=42$ ), the full Oregon dataset $(n=47)$, and a negative control Oregon dataset
( $n=47$ ) composed of 20 randomly selected genes. Moreover, since age is the most prominent risk factor for AMD, we also tested SVM performance with the inclusion of donor age as a covariate.

All SVM models achieved statistically significant AMD discrimination on every dataset except the randomized negative control (Figures S9 and S10 in Additional file 1). Based on the percentage of AMD donor samples that were correctly identified, SVM models generated from expression data alone achieved a cross-validation classification accuracy of $81 \%$ on the Iowa test data $\left(P=1.6 \times 10^{-5}\right.$; Figure 59 in Additional file 1$)$, an average classification accuracy of $71 \%$ on the Oregon dataset $\left(P=6.3 \times 10^{-4}\right.$; Figure S10a in Additional file 1), and an average accuracy of $55 \%$ for 20 randomly selected Oregon genes $(P=0.24$; Figure $\mathrm{S} 10 \mathrm{~b}$ in Additional file 1). After incorporating age, the cross-validation accuracy of the Iowa test data improved to $84 \%\left(P=3.3 \times 10^{-7}\right)$ and the average accuracy of the Oregon data improved to $72 \%\left(P=3.6 \times 10^{-4}\right)$. It is worth noting that the predictive accuracy of our SVM models may be underestimated on the Oregon cohort due to possible non-diagnosis of AMD. For example, many of the RPE-choroid Global Up disease module transcripts are also found at elevated levels in what might be pre- or subclinical stages of AMD (for example, MD1 and MD2; Figures $2 \mathrm{a}$ and $3 \mathrm{a}$ ). Since most misclassified Oregon donors represent the oldest individuals at highest risk for developing AMD (Figure 3b; Figure S10a in Additional file 1), and because Oregon donors were not graded postmortem, such individuals may have exhibited early stages of AMD. Regardless, these data collectively validate our approach for the identification of AMD-related genes, and demonstrate that genes within the RPE-choroid Global Up disease module are global biomarkers of AMD.

\section{Functional enrichments of AMD phenotype-specific modules}

In addition to Global Up modules, nearly three-quarters of the remaining disease modules $(19 / 26)$ have significant functional enrichments (Table S4 in Additional file 6). Like the RPE-choroid Global Up module, inflammation is a prevalent functional category for other AMD phenotype-specific RPE-choroid modules (pre-AMD (MD1), Dry AMD, GA, and CNV Up), indicating that distinct inflammatory elements may contribute to AMD phenotypic diversity.

In particular, the two advanced AMD phenotypes, GA and $\mathrm{CNV}$, are highly enriched in functional pathways and cellular activities. The RPE-choroid CNV Up module contains numerous genes associated with vascularization, including genes associated with extracellular matrix $(P=$ $\left.4.6 \times 10^{-7}\right)$ and circulatory system development $(P=2.5 \times$ $\left.10^{-5}\right)$. The RPE-choroid GA Up module is robustly enriched in apoptotic processes $\left(P=9.6 \times 10^{-9}\right)$, consistent 


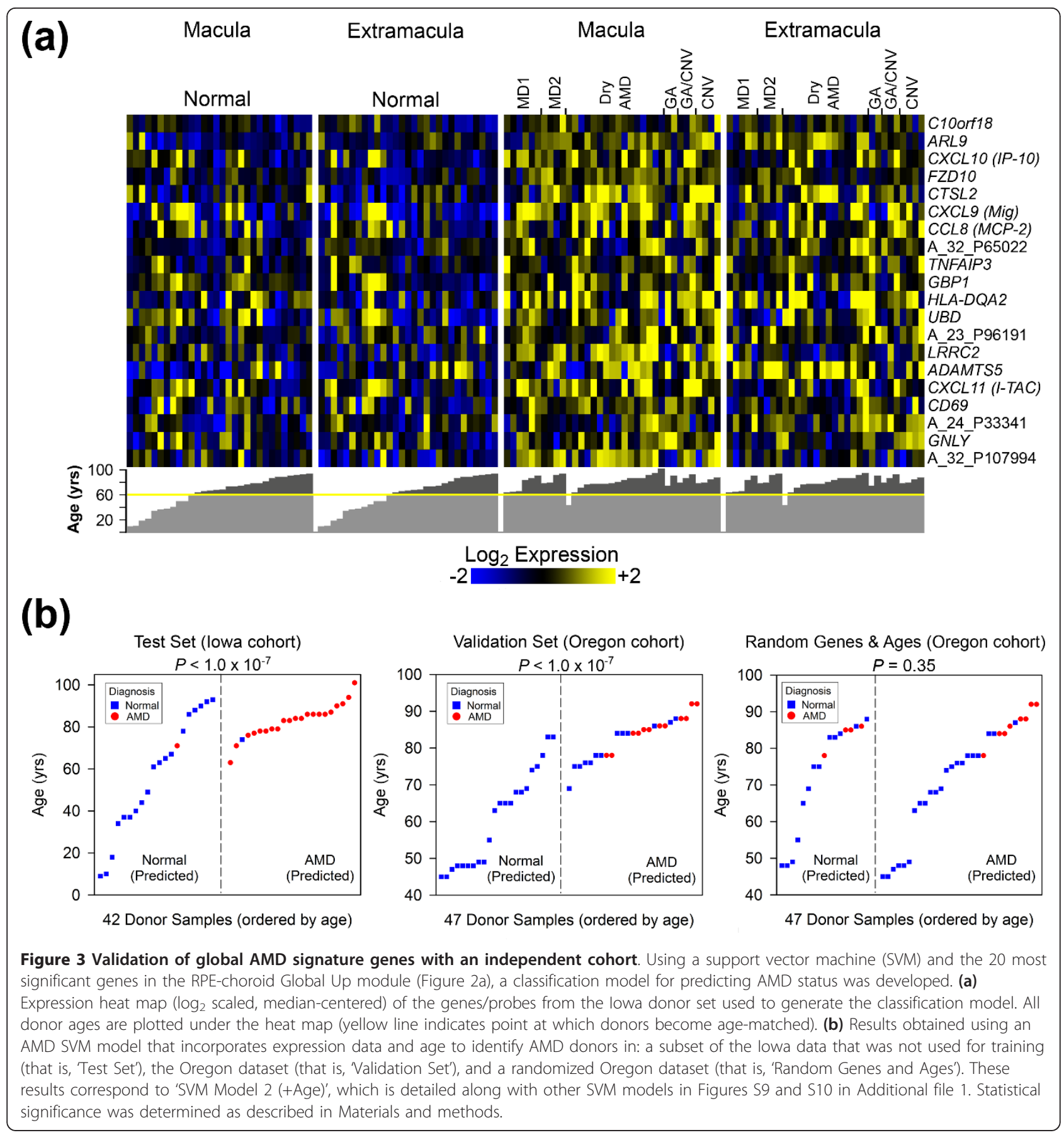

with previous observations implicating cell death in geographic atrophy $[79,123]$. In retinal tissues, both $\mathrm{CNV}$ and GA show elevated expression of major histocompatibility complex I genes $(P<0.01)$ and genes involved in neurogenesis $(P<0.05)$, along with a concomitant decrease in transcripts critical for photoreceptor function in the macula (GA, $P=1.5 \times 10^{-4}$; CNV, $\left.P=7.3 \times 10^{-9}\right)$, including red and green cone opsins (OPN1LW and OPN1MW) previously associated with the degenerative effects of drusen [124]. The Retina CNV Down module also includes rhodopsin $(R H O)$ and photoreceptor outer segment genes. Importantly, no evidence for elevated photoreceptor transcript levels was seen in the corresponding RPE-choroid samples, ruling out loss of photoreceptors during dissection due to the presence of a disciform scar. These data thus reaffirm the characteristic phenotypes of these two advanced AMD phenotypes, and identify numerous differentially expressed genes for further study. 
In contrast to the advanced AMD phenotypes, $\mathrm{CNV}$ and GA, our analysis did not reveal notable functional features of Dry AMD (non-GA) in the RPE-choroid beyond cell-mediated immune responses (Table $\mathrm{S} 4$ in Additional file 6). Similarly, prominent phenotype-specific functional enrichments were not observed in the retina, aside from a reduction of neuronal processes in both MD2 and pooled samples of MD1 and MD2 (MD Down). These results may reflect the heterogeneity of classification systems applied to delineate putative stages (or phenotypes) of MD1, MD2, and Dry AMD (Table 1).

\section{Functional networks delineate global and advanced-stage AMD phenotypes}

As a first step toward developing a systems-level molecular model of AMD, we examined the disease modules for evidence of protein-protein associations. We found six disease modules with significant enrichment in known and predicted associations $(P<0.01$; Figure S11 in Additional file 1). Further analysis of the three most significant RPE-choroid modules (RPE-choroid Global, $\mathrm{CNV}$, and GA Up) revealed a protein interactome consisting of both direct and indirect interactions among 95 proteins (83 disease module genes) divided into cellmediated immunity, angiogenesis/extracellular matrix remodeling, and apoptosis subnetworks (Figure 4a). To explore gene expression within this interactome across each AMD and potential pre-AMD phenotype, normalized expression levels from the macular RPE-choroid were superimposed onto the network (Figure 4b) and mean levels were plotted (Figure 4c). (Both macular and extramacular expression levels, depicted as heat maps, are shown in Figure S12 in Additional file 1.) As illustrated in Figure 4b, c, transcripts in the cell-mediated immunity subnetwork are found at higher levels in the macula for every phenotype, except MD2 (consistent with Figure 2a, right). Furthermore, apoptosis and extracellular matrix remodeling subnetwork transcripts are more abundant in GA and CNV, respectively, consistent with our previous results (Table S4 in Additional file 6). Moreover, this interactome is strikingly enriched in genes associated with AMD in prior literature (10/83 differential expressed network elements; $P=3.3 \times 10^{-7}$ ). A table of previously reported genes/gene products cross-referenced with the interactome and disease module genes is provided as Table S2 in Additional file 3 (see Materials and methods for details).

Separately, we assembled a retina interactome (Figure $5 a)$ consisting of significantly connected proteins from the Global Up and CNV Up modules $(P<0.01$; Figure S11 in Additional file 1), along with phototransduction proteins functionally enriched in the CNV Down module. Normalized macular expression levels indicate a tight coregulation of complement/wound response and neurogenesis subnetworks (Figure 5b, c; see Figure S13 in Additional file 1 for both macula and extramacula). Furthermore, there is a progressive decrease of the phototransduction subnetwork RNAs from Dry AMD to GA to CNV that is virtually macula-specific (Figure S13 in Additional file 1). Finally, like the RPE-choroid, the retina interactome significantly overlaps with previously studied AMD genes/gene products (13/92 network elements; $P=7.5 \times 10^{-10}$; Table S2 in Additional file 3). These findings further validate our transcriptome data and support the conventional classification of AMD into functionally distinct and increasingly severe phenotypes.

\section{Discussion}

In this study, we analyzed transcriptome profiles of the tissues most affected in AMD, the RPE-choroid and neural retina. Using pairwise statistical analysis in combination with significance score-based clustering, we identified 32 novel gene expression signatures, termed disease modules, associated with major clinical AMD phenotypes as well as two potential pre-AMD phenotypes (Figure 2). Among the 32 disease modules, we discovered 4 disease modules common to multiple disease phenotypes (Figure 2). Next, we showed by SVM analysis that expression levels of the top 20 genes in the RPE-choroid Global Up module (Iowa cohort) can significantly discriminate between clinically documented cases of AMD and normal donors in an independent RPE-choroid dataset (Oregon cohort). Finally, using disease module genes with statistically enriched functional concordance, we assembled detailed interactomes that reveal both global and phenotype-specific processes associated with AMD (Figures 4 and 5). Collectively composed of nearly 200 differentially expressed genes, these interactomes are statistically enriched in genes previously associated with AMD (23 total genes; Figures 4 and 5; Table S2 in Additional file 3), thus validating our analytical strategy and further implicating the previously unexplored network components in AMD pathology.

Our findings reveal that cell-based inflammatory responses within the RPE-choroid are a core feature of AMD. Remarkably, this global process is even detectable in one of the earliest potential stages of the disease prior to perceptible vision loss (MD1; Figures $4 \mathrm{~b}$ and $5 \mathrm{~b}$ ). Thus, Oregon donors classified by SVM models as $A M D$ (Figure S10a in Additional file 1), but initially labeled 'normal' (Materials and methods), may have been in the beginning stages of AMD. Recently, elevated levels of CXCL10 were reported in the sera and choroid of individuals with AMD [63], and elevated intraocular CCL2 levels were observed in neovascular AMD [64]. Here we show that all AMD phenotypes in the RPE-choroid are associated with elevated expression of all, or a subset, of the following chemokines: CXCL1, CXCL2, CXCL9, CXCL10, CXCL11, CCL2, and CCL8 (Figure 2a, right). 
(a)

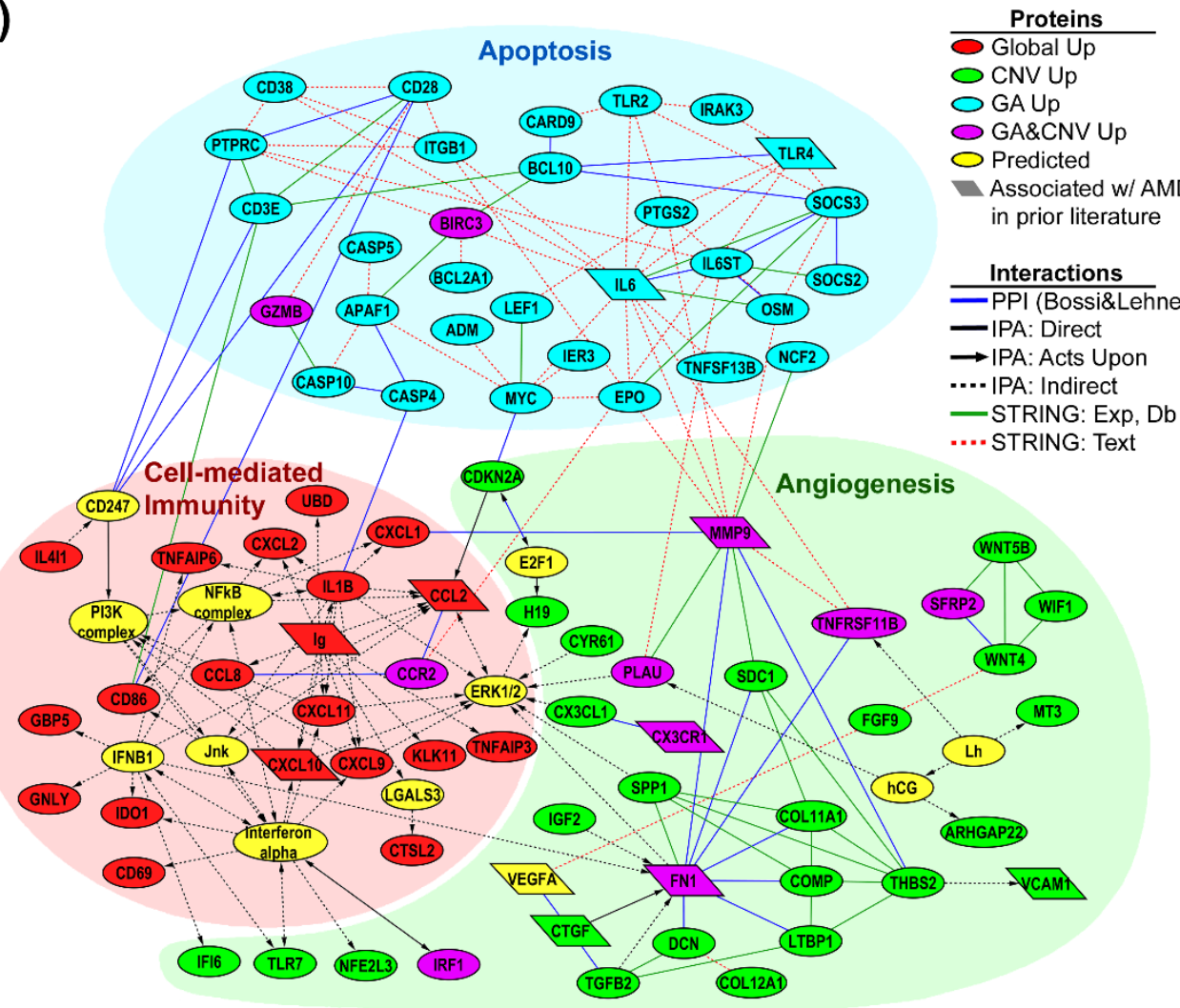

(b)

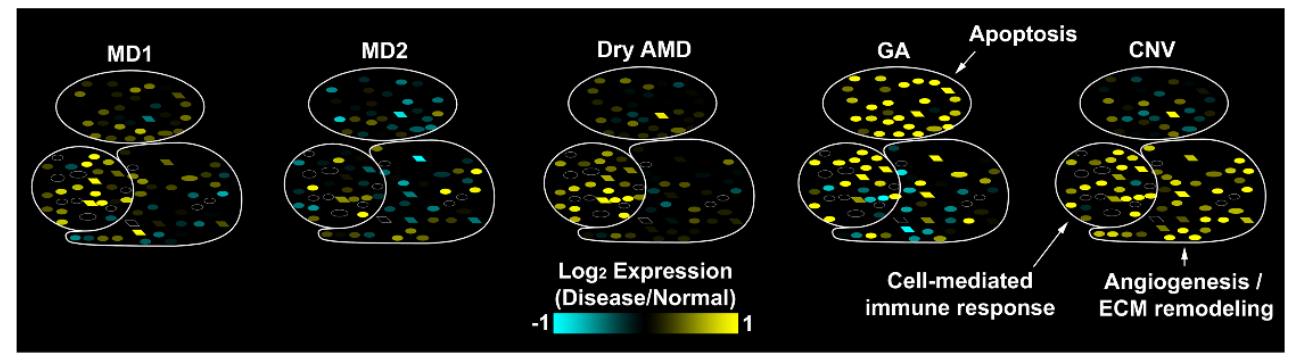

(c)

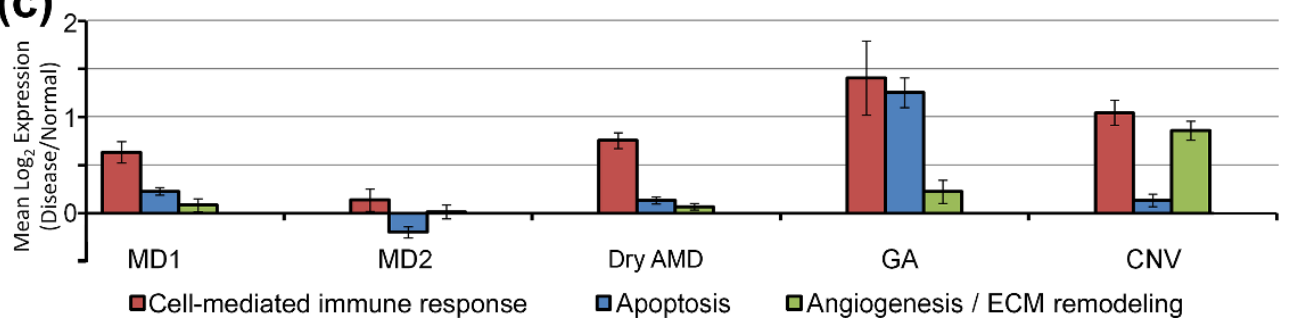

Figure 4 RPE-choroid AMD interactome: globally conserved and phenotype-specific subnetworks. (a) AMD interactome showing direct and indirect protein-protein interactions within RPE-choroid Global Up, CNV Up and GA Up disease modules assembled from three data sources: STRING [49], Ingenuity Pathway Analyzer (IPA), and the Bossi and Lehner [50] human protein-protein interaction dataset (PPI) (see Materials and methods). Gene products are represented by nodes, most of which are color-coded according to disease module. Yellow nodes represent genes predicted by IPA, with the exception of VEGFA, which was predicted manually and is highly expressed in our RPE-choroid expression data. Parallelogram-shaped nodes denote genes previously associated with AMD (Table S2 in Additional file 3). Individual immunoglobulin genes/ probes in the Global Up module were combined (see Materials and methods) and are represented as a single node ('Ig'). Exp, Db, and Text indicate Experimental, Knowledge/Database, and Text-mining components of the STRING interaction score, respectively. (b) Heat maps depict differential expression of network genes in the macula of each AMD/pre-AMD phenotype (also see Figure S12 in Additional file 1). Differential expression was calculated as the geometric mean of each gene normalized to age-matched normal donor samples ( $\geq 60$ years). Only pure GA and CNV are represented. (For data including GA/CNV donor samples, see Figure S12 in Additional file 1). (c) Bar plot depicting mean of expression data in (b), shown as a function of AMD/pre-AMD phenotype. Error bars represent standard error of the mean. 


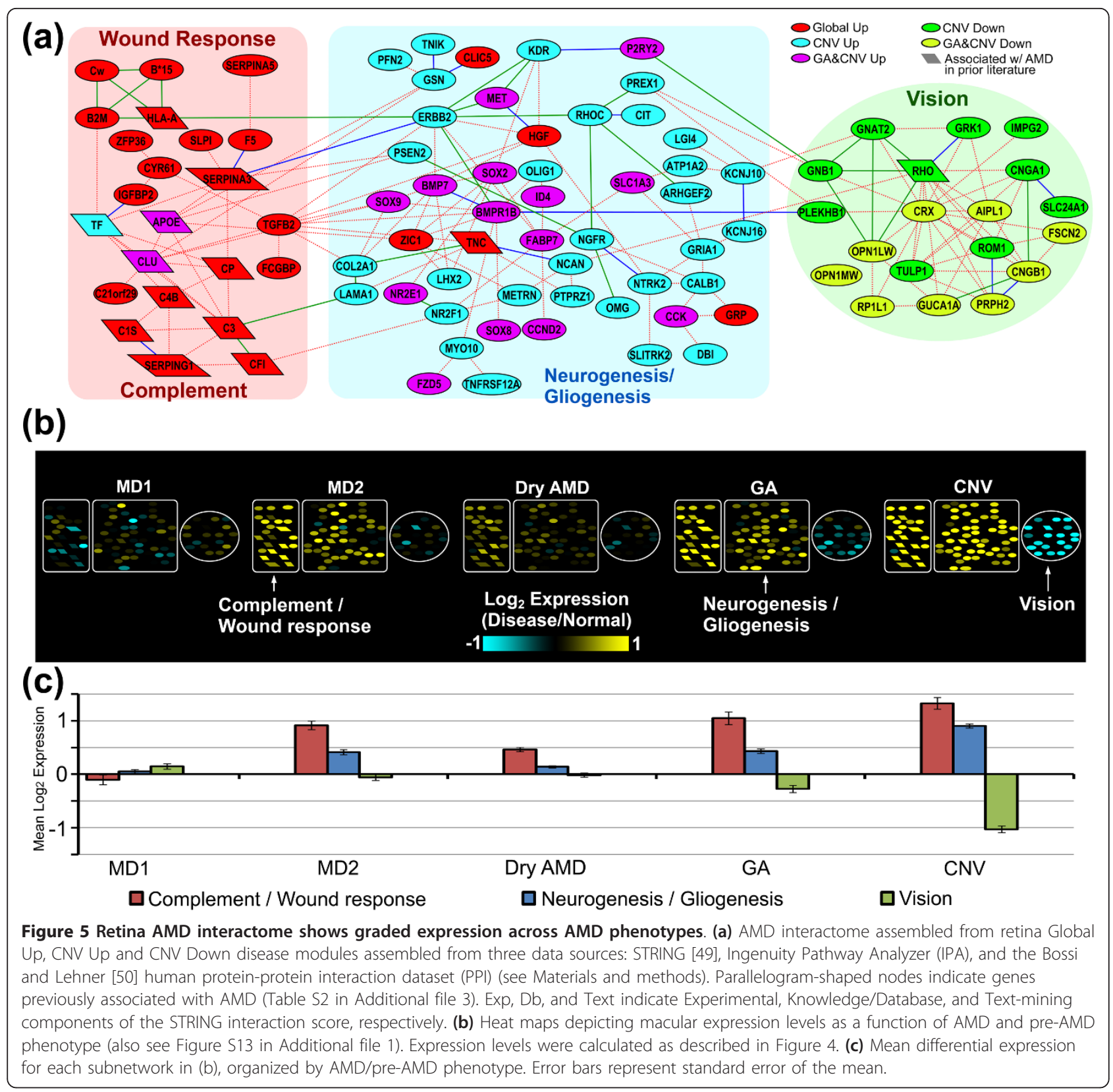

These chemokines are known to recruit macrophages, dendritic cells, granulocytes, CD4+ Th1 cells, CD8+ T cells, and natural killer cells to damaged tissue [125]. Although activated macrophages and other leukocytes are known expressers, most of these chemokines are also expressed in cultures of human fetal RPE following exposure to IL1B [126]. (Notably, IL1B is found in the RPEchoroid Global Up module.) Determining the cellular source(s), context-specific cellular target(s), and regulatory mechanism(s) of AMD-associated chemokines remains an important goal of future work.

A number of other factors in the RPE-choroid Global Up module further implicate a cellular immune response in AMD. For example, CD86 is expressed in drusen-associated dendritic cells [6], CD69 is expressed in activated leukocytes [127], and ILI41 and the elastolytic protease CTSL2 are both expressed by macrophages upon activation [128]. In addition, the up-regulation of immunoglobulin genes supports an adaptive, autoimmune response in AMD that is consistent with previous reports of immunoglobulins in drusen and drusen-associated RPE [129] as well as anti-carboxyethylpyrrole adduct antibodies [130] and anti-retinal antigen autoantibodies [131-133] in AMD sera.

We also identified a Retina Global Up module composed of more than 50 genes common to sub-clinical 
AMD (MD2), Dry AMD (non-GA), neovascular AMD, and GA, but not to donors at risk for AMD with macular hard drusen alone (MD1) with little to no vision loss (Figure $2 \mathrm{~b}$, right, and Figure $5 \mathrm{~b}$ ). In addition to wound response genes (for example, TGFB2, CYR61), this module is highly enriched in complement genes previously associated with AMD (C3, C4, C1S, CFI, SERPING1; Table S4 in Additional file 6). Given the prevailing view that the role of complement in AMD is linked to deposition of the terminal complement complex in drusen and the capillary pillars of the choroid $[6-8,10]$, this finding is unanticipated, and indicates a possible direct role for complement in retinal degeneration. In addition, the up-regulation of both complement and major histocompatibility complex I genes $(H L A-A / B / C$ genes, and $B 2 M$ ) in the Global Up module, along with $A P O E$ elevation in the Retina GA Up and CNV Up modules (Figure $5 b)$ may reflect activation of resident microglia in the retina $[134,135]$. This is further supported by reports of a similar microglial immunological response in a CX3CR $1^{-1-}$ mouse model of AMD [135], as well as in animal models of photo-induced retinal damage $[136,137]$.

Finally, by integrating functionally enriched gene sets with interactome data, this work reveals many attractive candidates for AMD therapeutics and diagnostics (Figures 4 and 5). Examples of wet AMD candidate targets within the RPE-choroid interactome (Figure 4) include $I G F 2$, an imprinted gene adjacent to $H 19$ (also in Figure 4) whose product up-regulates VEGF expression [138], CYR61, a matricellular protein that modulates angiogenesis and apoptosis [139], and SPP1, a matricellular CFH binding protein that is both a promoter of VEGFinduced endothelial migration and an immunomodulator $[140,141]$. GA Up genes with potential relevance for pharmaceutical intervention include $E P O$, which inhibits oxidative damage-induced apoptosis in cultured RPE [142] and IL6, a mediator of RPE degeneration [143]. Furthermore, the interactome genes constitute only a small subset of all identified disease module genes with potential utility for AMD therapy. For example, 62 angiogenesis-related genes in the RPE-choroid CNV Up module encode secreted proteins (Table S3 in Additional file 5), any one of which may represent an effective drug target.

\section{Conclusions}

In this study, we discovered novel global biomarkers, phenotype-specific gene sets, and functional networks associated with AMD. Although further studies will be needed to elucidate the specific cell populations responsible for gene expression changes in AMD, and to further validate and confirm the identity of these AMDassociated genes, our results represent a major step toward assembling a systems-level model of AMD, and establish a benchmark for future studies that incorporate both greater cohort sampling and higher-resolution genomic profiling (for example, employing microdissection and next-generation sequencing methodologies). Fundamentally, this work demonstrates that immune responsiveness is a central, unifying process that characterizes the molecular pathology of all AMD phenotypes $[6,7,10]$, consistent with the hypothesis that AMD is a singular disease with multiple outcomes. In summary, these data support the model that aging, environmental stressors, and genetic predisposition all hasten the onset and progression of cell-based immunological events, leading to a state of chronic local inflammation that mediates the development of the neovascular and/or atrophic changes characteristic of advanced AMD. In light of these results, we suggest that pharmaceuticals targeting core immunological processes may have broad efficacy for all clinical manifestations of AMD.

\section{Additional material}

\section{Additional file 1: Figures S1 to S13. Supplemental figures and} corresponding legends.

Additional file 2: Table S1. Differentially expressed genes between AMD and age-matched normal donor samples in the RPE-choroid (sheet 1, Table S1, RPE-choroid) and retina (sheet 2, Table S1, Retina).

Additional file 3: Table S2. Curated list of genes previously associated with AMD.

Additional file 4: Assessment of RNA and microarray quality. Description of analytical procedures used to determine the quality of the RNA and microarray data.

Additional file 5: Table S3. RPE-choroid (sheet 1, Table S3, RPE-choroid) and retina (sheet 2, Table S3, Retina) disease module gene lists and associated data.

Additional file 6: Table S4. Disease module functional enrichments.

\section{Abbreviations}

AMD: age-related macular degeneration; CNV: choroidal neovascularization or 'wet AMD'; GA: geographic atrophy; IPA: Ingenuity Pathway Analyzer; MD1: pre-AMD; MD2: sub-clinical pre-AMD; PPI: protein-protein interaction; RPE: retinal pigmented epithelium; SVM: support vector machine.

\section{Acknowledgements}

This work was supported by a grant from the National Eye Institute (EY R24 EY017404), benefactors to the UCSB Center for the Study of Macular Degeneration, grants from Allergan, Inc. and the Alcon Research Institute (GSH), and unrestricted grants to the University of Utah Department of Ophthalmology and Visual Sciences and the University of lowa Department of Ophthalmology and Visual Sciences from Research to Prevent Blindness, Inc.

\section{Author details}

${ }^{1}$ Center for the Study of Macular Degeneration, Neuroscience Research Institute, Biological Sciences 2 Building, University of California, Santa Barbara, CA 93106-5060, USA. Department of Ophthalmology and Visual Sciences, University of lowa, 200 Hawkins Drive lowa City, IA 52242-1109, USA. ${ }^{3}$ Department of Ophthalmology and Visual Sciences, John A Moran Eye Center, University of Utah, 65 Mario Capecchi Drive, Salt Lake City, UT 84132 5230, USA. ${ }^{4}$ Molecular, Cellular, and Developmental Biology Department, Life 
Sciences Building, University of California, Santa Barbara, CA 93106-9610, USA. ${ }^{5}$ Current address: Institute for Stem Cell Biology and Regenerative Medicine, Stanford University School of Medicine, 265 Campus Drive, Stanford, CA 94305, USA.

\section{Authors' contributions}

AMN designed the study, analyzed the data and drafted the manuscript. NBG, LH, NM, CMR, and MAM assisted in laboratory research. JBC contributed to data interpretation and manuscript revision. GSH, DHA, and LVJ conceived of the study and contributed to manuscript revision. MJR conceived of and designed the study, analyzed the data and drafted the manuscript. All authors read and approved the final manuscript.

\section{Competing interests}

GSH received funding from Alcon Research Institute and Allergan, Inc. No other authors have any competing interests.

Received: 17 August 2011 Revised: 18 January 2012

Accepted: 24 February 2012 Published: 24 February 2012

\section{References}

1. Cohen $L H$, Noell WK: Relationships between visual function and metabolism. In Biochemistry of the Retina. Edited by: Graymor CN. Orlando, FL: Academic Press Inc; 1965:35-50.

2. Wangsa-Wirawan ND, Linsenmeier RA: Retinal oxygen: fundamental and clinical aspects. Arch Ophthalmol 2003, 121:547-557.

3. Foulds WS: The choroidal circulation and retinal metabolism - an overview. Eye 1990, 4:243-248.

4. Klein R, Chou CF, Klein BE, Zhang X, Meuer SM, Saaddine JB: Prevalence of age-related macular degeneration in the US population. Arch Ophthalmol 2011, 129:75-80

5. Bird AC, Bressler NM, Bressler SB, Chisholm IH, Coscas G, Davis MD, de Jong PT, Klaver CC, Klein BE, Klein R, Mitchell P, Sarks JP, Sarks SH, Soubrane G, Taylor HR, Vingerling JR: An international classification and grading system for age-related maculopathy and age-related macular degeneration. Surv Ophthalmol 1995, 39:367-374.

6. Hageman GS, Luthert PJ, Victor Chong NH, Johnson LV, Anderson DH, Mullins RF: An integrated hypothesis that considers drusen as biomarkers of immune-mediated processes at the RPE-Bruch's membrane interface in aging and age-related macular degeneration. Prog Retin Eye Res 2001, 20:705-732.

7. Anderson DH, Mullins RF, Hageman GS, Johnson LV: A role for local inflammation in the formation of drusen in the aging eye. Am J Ophthalmol 2002, 134:411-431.

8. Gehrs KM, Jackson JR, Brown EN, Allikmets R, Hageman GS: Complement, age-related macular degeneration and a vision of the future. Arch Ophthalmol 2010, 128:349-358.

9. Gehrs KM, Anderson DH, Johnson LV, Hageman GS: Age-related macular degeneration- emerging pathogenetic and therapeutic concepts. Ann Med 2006, 38:450-471.

10. Anderson DH, Radeke MJ, Gallo NB, Chapin EA, Johnson PT, Curletti CR, Hancox LS, Hu J, Ebright JN, Malek G, Hauser MA, Rickman CB, Bok D, Hageman GS, Johnson LV: The pivotal role of the complement system in aging and age-related macular degeneration: hypothesis re-visited. Prog Retin Eye Res 2010, 29:95-112.

11. Age-Related Eye Disease Study Research Group: Risk factors associated with age-related macular degeneration. A case-control study in the agerelated eye disease study: Age-Related Eye Disease Study Report Number 3. Ophthalmology 2000, 107:2224-2232.

12. Age-Related Eye Disease Study Research Group: A randomized, placebocontrolled, clinical trial of high-dose supplementation with vitamins $C$ and $\mathrm{E}$, beta carotene, and zinc for age-related macular degeneration and vision loss: AREDS report no. 8. Arch Ophthalmol 2001, 119:1417-1436.

13. Smith W, Assink J, Klein R, Mitchell P, Klaver CC, Klein BE, Hofman A, Jensen S, Wang JJ, de Jong PT: Risk factors for age-related macular degeneration: Pooled findings from three continents. Ophthalmology 2001, 108:697-704

14. McCarty CA, Mukesh BN, Fu CL, Mitchell P, Wang HH, Taylor HR: Risk factors for age-related maculopathy: the Visual Impairment Project. Arch Ophthamol 2001, 119:1455-1462.
15. Edwards AO, Ritter R, Abel K, Manning A, Panhuysen C, Farrer LA: Complement factor $\mathrm{H}$ polymorphism and age-related macular degeneration. Science 2005, 308:421-424.

16. Klein RJ, Zeiss C, Chew EY, Tsai JY, Sackler RS, Haynes C, Henning AK, SanGiovanni JP, Mane SM, Mayne ST, Bracken MB, Ferris FL, Ott J, Barnstable C, Hoh J: Complement factor $\mathrm{H}$ polymorphism in age-related macular degeneration. Science 2005, 308:385-389.

17. Haines JL, Hauser MA, Schmidt S, Scott WK, Olson LM, Gallins P, Spencer KL, Kwan SY, Noureddine M, Gilbert JR, Schnetz-Boutaud N, Agarwal A, Postel EA, Pericak-Vance MA: Complement factor $\mathrm{H}$ variant increases the risk of age-related macular degeneration. Science 2005, 308:419-421.

18. Hageman GS, Anderson DH, Johnson LV, Hancox LS, Taiber AJ, Hardisty LI, Hageman JL, Stockman HA, Borchardt JD, Gehrs KM, Smith RJ, Silvestri G, Russell SR, Klaver CC, Barbazetto I, Chang S, Yannuzzi LA, Barile GR, Merriam JC, Smith RT, Olsh AK, Bergeron J, Zernant J, Merriam JE, Gold B, Dean M, Allikmets R: A common haplotype in the complement regulatory gene factor $\mathrm{H}$ (HF1/CFH) predisposes individuals to agerelated macular degeneration. Proc Natl Acad Sci USA 2005, 102:7227-7232.

19. Gold B, Merriam JE, Zernant J, Hancox LS, Taiber AJ, Gehrs K, Cramer K, Neel J, Bergeron J, Barile GR, Smith RT, AMD Genetics Clinical Study Group, Hageman GS, Dean M, Allikmets R: Variation in factor B (BF) and complement component 2 (C2) genes is associated with age-related macular degeneration. Nat Genet 2006, 38:458-462.

20. Hageman GS, Hancox LS, Taiber AJ, Gehrs KM, Anderson DH, Johnson LV, Radeke MJ, Kavanagh D, Richards A, Atkinson J, Meri S, Bergeron J, Zernant J, Merriam J, Gold B, Allikmets R, Dean M, AMD Clinical Study Group: Extended haplotypes in the complement factor $\mathrm{H}$ (CFH) and CFHrelated (CFHR) family of genes protect against age-related macular degeneration: characterization, ethnic distribution and evolutionary implications. Ann Med 2006, 38:592-604

21. Yates JR, Sepp T, Matharu BK, Khan JC, Thurlby DA, Shahid H, Clayton DG, Hayward C, Morgan J, Wright AF, Armbrecht AM, Dhillon B, Deary IJ, Redmond E, Bird AC, Moore AT, Genetic Factors in AMD Study Group: Complement $\mathrm{C} 3$ variant and the risk of age-related macular degeneration. N Engl J Med 2007, 357:553-561.

22. Maller JB, Fagerness JA, Reynolds RC, Neale BM, Daly MJ, Seddon JM: Variation in complement factor 3 is associated with risk of age-related macular degeneration. Nat Genet 2007, 39:1200-1201.

23. Jakobsdottir J, Conley YP, Weeks DE, Mah TS, Ferrell RE, Gorin MB: Susceptibility genes for age-related maculopathy on chromosome 10q26. Am J Hum Genet 2005, 77:389-407.

24. Rivera A, Fisher SA, Fritsche LG, Keilhauer CN, Lichtner P, Meitinger T, Weber BH: Hypothetical LOC387715 is a second major susceptibility gene for age-related macular degeneration, contributing independently of complement factor $\mathrm{H}$ to disease risk. Hum Mol Genet 2005, 14:3227-3236.

25. Dewan A, Liu M, Hartman S, Zhang SS, Liu DT, Zhao C, Tam PO, Chan WM, Lam DS, Snyder M, Barnstable C, Pang CP, Hoh J: HTRA1 promoter polymorphism in wet age-related macular degeneration. Science 2006 314:989-992

26. Yang Z, Camp NJ, Sun H, Tong Z, Gibbs D, Cameron DJ, Chen H, Zhao Y, Pearson E, Li X, Chien J, Dewan A, Harmon J, Bernstein PS, Shridhar V, Zabriskie NA, Hoh J, Howes K, Zhang K: A variant of the HTRA1 gene increases susceptibility to age-related macular degeneration. Science 2006, 314:992-993.

27. Souied EH, Benlian P, Amouyel P, Feingold J, Lagarde JP, Munnich A, Kaplan J, Coscas G, Soubrane G: The $\varepsilon 4$ allele of the apolipoprotein E gene as a potential protective factor for exudative age-related macular degeneration. Am J Ophthalmol 1998, 125:353-359.

28. Klaver CC, Kliffen M, van Duijn CM, Hofman A, Cruts M, Grobbee DE, van Broeckhoven C, de Jong PT: Genetic association of apolipoprotein E with age-related macular degeneration. Am J Hum Genet 1998, 63:200-206.

29. Baird PN, Guida E, Chu DT, Vu HT, Guymer RH: The $\varepsilon 2$ and $\varepsilon 4$ alleles of the apolipoprotein gene are associated with age-related macular degeneration. Invest Ophthalmol Vis Sci 2004, 45:1311-1315.

30. Zareparsi S, Reddick AC, Branham KE, Moore KB, Jessup L, Thoms S, SmithWheelock M, Yashar BM, Swaroop A: Association of apolipoprotein E alleles with susceptibility to age-related macular degeneration in a large cohort from a single center. Invest Ophthalmol Vis Sci 2004, 45:1306-1310.

31. Fritsche LG, Freitag-Wolf $\mathrm{S}$, Bettecken T, Meitinger T, Keilhauer CN, Krawczak M, Weber BH: Age-related macular degeneration and functional 
promoter and coding variants of the apolipoprtoein E gene. Hum Mutat 2009, 30:1048-1053.

32. Chen W, Stambolian D, Edwards AO, Branham KE, Othman M, Jakobsdottir J, Tosakulwong N, Pericak-Vance MA, Campochiaro PA, Klein ML, Tan PL, Conley YP, Kanda A, Kopplin L, Li Y, Augustaitis KJ Karoukis AJ, Scott WK, Agarwal A, Kovach JL, Schwartz SG, Postel EA, Brooks M, Baratz KH, Brown WL, Complications of Age-Related Macular Degeneration Prevention Trial Research Group, Brucker AJ, Orlin A, Brown G, Ho A, et al: Genetic variants near TIMP3 and high-density lipoprotein-associated loci influence susceptibility to age-related macular degeneration. Proc Natl Acad Sci USA 2010, 107:7401-7406.

33. Neale BM, Fagerness J, Reynolds R, Sobrin L, Parker M, Raychaudhuri S, Tan PL, Oh EC, Merriam JE, Souied E, Bernstein PS, Li B, Frederick JM, Zhang K, Brantley MA Jr, Lee AY, Zack DJ, Campochiaro B, Campochiaro P, Ripke S, Smith RT, Barile GR, Katsanis N, Allikmets R, Daly MJ, Seddon JM: Genome-wide association study of advanced age-related macular degeneration identifies a role of the hepatic lipase gene (LIPC). Proc Natl Acad Sci USA 2010, 107:7395-7400.

34. Munro KM, Perreau VM: Current and future applications of transcriptomics for discovery in CNS disease and injury. Neurosignals 2009, 17:311-327.

35. Edelman LB, Eddy JA, Price ND: In silico models of cancer. Wiley Interdiscip Rev Syst Biol Med 2010, 2:438-459.

36. Radeke MJ, Peterson KE, Johnson LV, Anderson DH: Disease susceptibility of the human macula: differential gene transcription in the retinal pigmented epithelium/choroid. Exp Eye Res 2007, 85:366-380.

37. van Soest SS, de Wit GM, Essing AH, ten Brink JB, Kamphuis W, de Jong PT, Bergen AA: Comparison of human retinal pigment epithelium gene expression in macula and periphery highlights potential topographic differences in Bruch's membrane. Mol Vis 2007, 13:1608-1617.

38. Booij JC, ten Brink JB, Swagemakers SM, Verkerk AJ, Essing AH, van der Spek PJ, Bergen AA: A new strategy to identify and annotate human RPE-specific gene expression. PLOS ONE 2010, 5:e9341.

39. Strunnikova NV, Maminishkis A, Barb JJ, Wang F, Zhi C, Sergeev Y, Chen W, Edwards AO, Stambolian D, Abecasis G, Swaroop A, Munson PJ, Miller SS: Transcriptome analysis and molecular signature of human retinal pigment epithelium. Hum Mol Genet 2010, 19:2468-2486.

40. Lederman M, Weiss A, Chowers I: Association of neovascular age-related macular degeneration with specific gene expression patterns in peripheral white blood cells. Invest Ophthalmol Vis Sci 2010, 51:53-58.

41. van Leeuwen R, Klaver CC, Vingerling JR, Hoffman A, de Jong PT: The risk and natural course of age-related maculopathy: follow-up at $61 / 2$ years in the Rotterdam study. Arch Ophthalmol 2003, 121:519-526.

42. Age-Related Eye Disease Study Research Group: The Age-Related Eye Disease Study system for classifying age-related macular degeneration from stereoscopic color fundus photographs: the Age-Related Eye Disease Study Report Number 6. Am J Ophthalmol 2001, 132:668-681.

43. Fisher RA, Yates F: Statistical Tables for Biological, Agricultural and Medical Research. Oliver and Boyd, London, England: Hafner Press; 1948.

44. Storey JD, Tibshirani R: Statistical significance for genomewide studies. Proc Natl Acad Sci USA 2003, 100:9440-9445.

45. Bolstad BM, Irizarry RA, Astrand M, Speed TP: A comparison of normalization methods for high density oligonucleotide array data based on variance and bias. Bioinformatics 2003, 19:185-193.

46. Newman AM, Cooper JB: AutoSOME: a clustering method for identifying gene expression modules without prior knowledge of cluster number. BMC Bioinformatics 2010, 11:117.

47. Reich M, Liefeld T, Gould J, Lerner J, Tamayo P, Mesirov JP: GenePattern 2.0. Nat Genet 2006, 38:500-501

48. Radmacher MD, MCShane LM, Simon R: A paradigm for class prediction using gene expression profiles. J Comput Biol 2002, 9:505-511.

49. Jensen L, Kuhn M, Stark M, Chaffron S, Creevey C, Muller J, Doerks T, Julien P, Roth A, Simonovic M, Bork P, von Mering C: STRING 8 - a global view on proteins and their functional interactions in 630 organisms. Nucleic Acids Res 2009, 37:D412-D416.

50. Bossi A, Lehner B: Tissue specificity and the human protein interaction network. Mol Syst Biol 2009, 5:260.

51. Chen J, Bardes EE, Aronow BJ, Jegga AG: ToppGene Suite for gene list enrichment analysis and candidate gene prioritization. Nucleic Acids Res 2009, 37:W305-W311.
52. Huang DW, Sherman BT, Lempicki RA: Bioinformatics enrichment tools: paths toward the comprehensive functional analysis of large gene lists. Nucleic Acids Res 2009, 37:1-13.

53. Shannon P, Markiel A, Ozier O, Baliga NS, Wang JT, Ramage D, Amin N, Schwikowski B, Ideker T: Cytoscape: a software environment for integrated models of biomolecular interaction networks. Genome Res 2003, 13:2498-2504.

54. Allikmets R, Shroyer NF, Singh N, Seddon JM, Lewis RA, Bernstein PS, Peiffer A, Zabriskie NA, Li Y, Hutchinson A, Dean M, Lupski JR, Leppert M: Mutation of the Stargardt disease gene (ABCR) in age-related macular degeneration. Science 1997, 277:1805-1807.

55. Hamdi HK, Reznik J, Castellon R, Atilano SR, Ong JM, Udar N, Tavis JH, Aoki AM, Nesburn AB, Boyer DS, Small KW, Brown DJ, Kenney MC: Alu DNA polymorphism in ACE gene is protective for age-related macular degeneration. Biochem Biophys Res Commun 2002, 295:668-672.

56. Crabb JW, Miyagi M, Gu X, Shadrach K, West KA, Sakaguchi H, Kamei M, Hasan A, Yan L, Rayborn ME, Salomon RG, Hollyfield JG: Drusen proteome analysis: an approach to the etiology of age-related macular degeneration. Proc Natl Acad Sci USA 2002, 99:14682-14687.

57. Yuan X, Gu X, Crabb JS, Yue X, Shadrach K, Hollyfield JG, Crabb JW: Quantitative proteomics: comparison of the macular bruch membrane/ choroid complex from age-related macular degeneration and normal eyes. Mol Cell Proteomics 2010, 9:1031-1046.

58. Wang L, Clark ME, Crossman DK, Kojima K, Messinger JD, Mobley JA, Curcio CA: Abundant lipid and protein components of drusen. PLOS ONE 2010, 5:e10329.

59. Ethen CM, Reilly C, Feng X, Olsen TW, Ferrington DA: The proteome of central and peripheral retina with progression of age-related macular degeneration. Invest Ophthalmol Vis Sci 2006, 47:2280-2290.

60. Nordgaard CL, Karunadharma PP, Feng X, Olsen TW, Ferrington DA: Mitochondrial proteomics of the retinal pigment epithelium at progressive stages of age-related macular degeneration. Invest Ophthalmol Vis Sci 2008, 49:2848-2855.

61. Nordgaard CL, Berg KM, Kapphahn RJ, Reilly C, Feng X, Olsen TW, Ferrington DA: Proteomics of the retinal pigment epithelium reveals altered protein expression at progressive stages of age-related macular degeneration. Invest Ophthalmol Vis Sci 2006, 47:815-822.

62. An E, Lu X, Flippin J, Devaney JM, Halligan B, Hoffman EP, Strunnikova N, Csaky K, Hathout Y: Secreted proteome profiling in human RPE cell cultures derived from donors with age related macular degeneration and age matched healthy donors. J Proteome Res 2006, 5:2599-2610.

63. Mo FM, Proia AD, Hohnson WH, Cyr D, Lashkari K: Interferon $y$-inducible protein-10 and eotaxin as biomarkers in age-related macular degeneration. Invest Ophthalmol Vis Sci 2010, 51:4226-4236.

64. Jonas JB, Tao Y, Neumaier M, Findeisen P: Monocyte chemoattractant protein 1, intercellular adhesion molecule 1, and vascular cell adhesion molecule 1 in exudative age-related macular degeneration. Arch Ophthalmol 2010, 128:1281-1286.

65. Guymer RH, Tao LW, Goh JK, Liew D, Ischenko O, Robman LD, Aung K, Cipriani T, Cain M, Richardson AJ, Baird PN, Langham R: Identification of urinary biomarkers for age-related macular degeneration. Invest Ophthalmol Vis Sci 2011, 52:4639-4644.

66. Ezzat MK, Hann CR, Vuk-Pavlovic S, Pulido JS: Immune cells in the human choroid. Br J Ophthalmol 2008, 92:976-980.

67. Fagerness JA, Maller JB, Neale BM, Reynolds RC, Daly MJ, Seddon JM: Variation near complement factor I is associated with risk of advanced AMD. Eur J Hum Genet 2009, 17:100-104.

68. Newsome DA, Swartz M, Leone NC, Hewitt AT, Wolford F, Miller ED: Macular degeneration and elevated serum ceruloplasmin. Invest Ophthalmol Vis Sci 1986, 27:1675-1680.

69. Vine AK, Stader J, Branham K, Musch DC, Swaroop A: Biomarkers of cardiovascular disease as risk factors for age-related macular degeneration. Ophthalmology 2005, 112:2076-2080.

70. Boekhoorn SS, Vingerling HR, Witteman JC, Hofman A, de Jong PT: Creactive protein level and risk of aging macula disorder: Rotterdam Study. Arch Ophthalmol 2007, 125:1396-1401.

71. Klein R, Knudtson MD, Klein BE, Wong TY, Cotch MF, Liu K, Cheng CY, Burke GL, Saad MF, Jacobs DR Jr, Sharrett AR: Inflammation, complement factor $h$, and age-related macular degeneration: the Multi-ethnic Study of Atherosclerosis. Ophthalmology 2008, 115:1742-1749. 
72. Seddon JM, George S, Rosner B, Rifai N: Progression of age-related macular degeneration: prospective assessment of C-reactive protein, interleukin 6, and other cardiovascular biomarkers. Arch Ophthalmol 2005 123:774-782.

73. Zurdel J, Finckh U, Menxer G, Nitsch RM, Richard G: CST3 genotype associated with exudative age related macular degeneration. $\mathrm{Br} J$ Ophthalmol 2002, 86:214-219.

74. Klein R, Knudtson MD, Lee KE, Klein BE: Serum cystatin C level, kidney disease markers, and incidence of age-related macular degeneration: the Beaver Dam Eye Study. Arch Ophthalmol 2009, 127:193-199.

75. He S, Jin ML, Worpel V, Hinton DR: A role for connective tissue growth factor in the pathogenesis of choroidal neovascularization. Arch Ophthalmol 2003, 121:1283-1288.

76. Watanabe D, Takagi H, Suzuma K, Oh H, Ohashi H, Honda Y: Expression of connective tissue growth factor and its potential role in choroidal neovascularization. Retina 2005, 25:911-918.

77. Tuo J, Smith BC, Bojanowski CM, Meleth AD, Gery I, Csaky KG, Chew EY, Chan CC: The involvement of sequence variation and expression of CX3CR1 in the pathogenesis of age-related macular degeneration. FASEB J 2004, 18:1297-1299.

78. Machalinska A, Safranow K, Dziedziejko V, Mozolewska-Piotrowska K, Paczkowska E, Klos P, Pius E, Grymula K, Wiszniewska B, Karczewicz D, Machalinski B: Different populations of circulating endothelial cells in patients with age-related macular degeneration: novel insight into pathogenesis. Invest Ophthalmol Vis Sci 2011, 52:93-100.

79. Kaneko H, Dridi S, Tarallo V, Gelfand BD, Fowler BJ, Cho WG, Kleinman ME, Ponicsan SL, Hauswirth WW, Chiodo VA, Karikó K, Yoo JW, Lee DK, Hadziahmetovic M, Song Y, Misra S, Chaudhuri G, Buaas FW, Braun RE, Hinton DR, Zhang Q, Grossniklaus HE, Provis JM, Madigan MC, Milam AH, Justice NL, Albuquerque RJ, Blandford AD, Bogdanovich S, Hirano Y, et al: DICER1 deficit induces Alu RNA toxicity in age-related macular degeneration. Nature 2011, 471:325-330.

80. Kimura K, Isashiki Y, Sonoda S, Kakiuchi-Matsumoto T, Ohba N: Genetic association of manganese superoxide dismutase with exudative agerelated macular dgeneration. Am J Ophthalmol 2000, 130:769-773.

81. Tuo J, Ning B, Bojanowski CM, Lin ZN, Ross RJ, Reed GF, Shen D, Jiao X, Zhou M, Chew EY, Kadlubar FF, Chan CC: Synergic effect of polymorphisms in ERCC6 5 ' flanking region and complement factor $\mathrm{H}$ on age-related macular degeneration predisposition. Proc Natl Acad Sci USA 2006, 103:9256-9261.

82. Jiang S, Moriarty-Craige SE, Li C, Lynn MJ, Cai J, Jones DP, Sternberg P: Associations of plasma-soluble fas ligand with aging and age-related macular degeneration. Invest Ophthalmol Vis Sci 2008, 49:1345-1349.

83. Stone EM, Braun TA, Russell SR, Kuehn MH, Lotery AJ, Moore PA, Eastman CG, Casavant TL, Sheffield VC: Missense variations in the fibulin 5 and age-related macular degeneration. N Engl J Med 2004, 351:346-353.

84. Lip PL, Blann AD, Hope-Ross M, Givson HM, Lip GY: Age-related macular degeneration is associated with increased vascular endothelial growth factor, hemorheology and endothelial dysfunction. Ophthalmology 2001, 108:705-710

85. Oz O, Aras Ates N, Tamer L, Yeldirim O, Adigüzel U: Glutathione Stransferase $\mathrm{M} 1, \mathrm{~T} 1$, and $\mathrm{P} 1$ gene polymorphism in exudative age-related macular degeneration: a preliminary report. Eur J Ophthalmol 2006, 16:105-110.

86. Güven $M$, Görgün E, Unal M, Yenerel $M$, Batar B, Küçümen B, Dinç UA, Güven GS, Ulus T, Yüksel A: Glutathione S-transferase M1, GST1 and GSTP1 genetic polymorphisms and the risk of age-related macular degeneration. Ophthalmic Res 2011, 46:31-37.

87. Sheridan CM, Pate $S$, Hiscott P, Wong D, Pattwell DM, Kent D: Expression of hypoxia-inducible factor- $1 a$ and $-2 a$ in human choroidal neovascular membranes. Graefes Arch Clin Exp Ophthalmol 2009, 247:1361-1367.

88. Goverdhan SV, Howell MW, Mullins RF, Osmond C, Hodgkins PR, Self J, Avery K, Lotery AJ: Association of HLA class I and class II polymorphism with age-related macular degeneration. Invest Ophthalmol Vis Sci 2005, 46:1726-1734

89. Schultz DW, Klein ML, Humpert AJ, Luzier CW, Persun V, Schain M, Mahan A, Runckel C, Cassera M, Vittal V, Doyle TM, Martin TM, Weleber RG, Francis PJ, Acott TS: Analysis of the ARMD1 locus: evidence that a mutation in HEMICENTIN-1 is associated with age-related macular degeneration in a large family. Hum Mol Genet 2003, 12:3315-3323.
90. Frank RN, Amin RH, Puklin JE: Antioxidant enzymes in the macular retinal pigment epithelium of eyes with neovascular age-related macular degeneration. Am J Ophthalmol 1999, 127:694-709.

91. Wu KH, Tan AG, Rochtchina E, Favaloro EJ, Williams A, Mitchell P, Wang JJ: Circulating inflammatory markers and hemostatic factors in age-related maculopathy: a population-based case-control study. Invest Ophthalmol Vis Sci 2007, 48:1983-1988.

92. Goverdhan SV, Ennis S, Hannan SR, Madhusudhana KC, Cree AJ, Luff AJ, Lotery AJ: Interleukin-8 promoter polymorphisms $-251 \mathrm{~A} / \mathrm{T}$ is a risk factor for age-related macular degeneration. Br J Ophthalmol 2008, 92:537-540.

93. Evereklioglu C, Doganay S, Er H, Cekmen M, Ozerol E, Otlu B: Serum leptin concentrations are decreased and correlated with disease severity in age-related macular degeneration: a preliminary study. Eye 2003, 17:350-355.

94. Haines JL, Schnetz-Boutaud N, Schmidt S, Scott WK, Agarwal A, Postel EA, Olson L, Kenealy SJ, Hauser M, Gilbert JR, Pericak-Vance MA: Functional candidate genes in age-related macular degeneration: significant association with VEGF, VLDLR, and LRP6. Invest Ophthalmol Vis Sci 2006, 47:329-335.

95. Steen B, Sejersen S, Berglin L, Seregard S, Kvanta A: Matrix metalloproteinases and metalloproteinase inhibitors in choroidal neovascular membranes. Invest Ophthalmol Vis Sci 1998, 39:2194-2200.

96. Fiotti N, Pedio M, Battaglia Parodi M, Altamura N, Uxa L, Guarnieri G, Giansante C, Ravalico G: MMP-9 microsatellite polymorphism and susceptibility to exudative form of age-related macular degeneration. Genet Med 2005, 7:272-277.

97. Chau KY, Sivaprasad S, Patel N, Donaldson TA, Luthert PJ, Chong NV: Plasma levels of matrix metalloproteinase-2 and -9 (MMP-2 and MMP-9) in age-related macular degeneration. Eye 2008, 22:855-859.

98. Bhutto IA, Baba T, Merges C, McLeod DS, Lutty GA: Low nitric oxide synthases (NOSs) in eyes with age-related macular degeneration (AMD). Exp Eye Res 2010, 90:155-167.

99. Cherepanoff S, McMenamin P, Gillies MC, Kettle E, Sarks SH: Bruch's membrane and choroidal macrophages in early and advanced agerelated macular degeneration. Br J Ophthalmol 2010, 94:918-925.

100. Ikeda T, Obayashi H, Hasegawa G, Nakamura N, Yoshikawa T, Imamura $Y$ Koizumi K, Kinoshita S: Paraoxonase gene polymorphisms and plasma oxidized low-density lipoprotein levels as possible risk factors for exudative age-related macular degeneration. Am J Ophthalmol 2001, 132:191-195.

101. Ethen CM, Feng X, Olsen TW, Ferrington DA: Declines in arrestin and rhodopsin in the macula with progression of age-related macular degeneration. Invest Ophthalmol Vis Sci 2005, 46:769-775.

102. Zerbib J, Seddon JM, Richard F, Reynolds R, Leveziel N, Benlian P, Borel P, Feingold J, Munnich A, Soubrane G, Kaplan J, Rozet JM, Souied EH: rs5888 variant of SCARB1 gene is a possible susceptibility factor for age-related macular degeneration. PLoS One 2009, 4:e7341.

103. Lin JM, Wan L, Tsai YY, Lin HJ, Tsai Y, Lee CC, Tsai CH, Tseng SH, Tsai FJ: Pigment epithelium-derived factor gene Met72Thr polymorphism is associated with increased risk of wet age-related macular degeneration. Am J Ophthalmol 2008, 145:716-721.

104. Holekamp NM, Bouck N, Volpert O: Pigment epithelium-derived factor is deficient in the vitreous of patients with choroidal neovascularization due to age-related macular degeneration. Am J Ophthalmol 2002, 134:220-227

105. Ennis S, Jomary C, Mullins R, Cree A, Chen X, Macleod A, Jones S, Collins A,

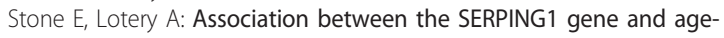
related macular degeneration: a two-stage case-control study. Lancet 2008, 372:1828-1834

106. Wysokinski D, Szaflik J, Sklodowska A, Kolodziejska U, Dorecka M, Romaniuk D, Wozniak K, Blasiak J, Szaflik JP: The A allele of the -576 G > A polymorphism of the transferrin gene is associated with the increased risk of age-related macular degeneration in smokers. Tohoku J Exp Med 2011, 223:253-261.

107. Yang Z, Stratton C, Francis PJ, Kleinman ME, Tan PL, Gibbs D, Tong Z, Chen H, Constantine R, Yang X, Chen Y, Zeng J, Davey L, Ma X, Hau VS, Wang C, Harmon J, Buehler J, Pearson E, Patel S, Kaminoh Y, Watkins S, Luo L, Zabriskie NA, Bernstein PS, Cho W, Schwager A, Hinton DR, Klein ML, Hamon SC, Simmons E, Yu B, Campochiaro B, Sunness JS, Campochiaro P, Jorde L, Parmigiani G, Zack DJ, Katsanis N, Ambati J, Zhang K: Toll-like 
receptor 3 and geographic atrophy in age-related macular degeneration. N Engl J Med 2008, 359:1456-1463.

108. Zareparsi S, Buraczynska M, Branham KE, Shah S, Eng D, Li M, Pawar H, Yashar BM, Moroi SE, Lichter PR, Petty HR, Richards JE, Abecasis GR, Elner VM, Swaroop A: Toll-like receptor 4 variant D299G is associated with susceptibility to age-related macular degeneration. Hum Mol Genet 2005, 14:1449-1455.

109. Tolppanen AM, Nevalainen T, Kolehmainen M, Seitsonen S, Immonen I, Uusitupa M, Kaarniranta K, Pulkkinen L: Single nucleotide polymorphisms of the tenomodulin gene (TNMD) in age-related macular degeneration. Mol Vis 2009, 15:762-770.

110. Churchill AJ, Carter JG, Lovell HC, Ramsden C, Turner SJ, Yeung A, Escardo J, Atan D: VEGF polymorphisms are associated with neovascular agerelated macular degenration. Hum Mol Genet 2006, 15:2955-2961.

111. Klein R, Klein BE, Linton KL: Prevalence of age-related maculopathy. The Beaver Dam Eye Study. Opthalmology 2007, 99:933-943.

112. Munch IC, Sander B, Kessel L, Hougaard JL, Taarnhøj NC, Sørenson TI, Kyvik KO, Larsen M: Heredity of small hard drusen in twins aged 20-46 years. Invest Ophthalmol Vis Sci 2007, 48:833-838.

113. Klein R, Klein BE, Knudtson MD, Meuer SM, Swift M, Gangnon RE: Fifteenyear cumulative incidence of age-related macular degeneration: the Beaver Dam Eye Study. Opthalmology 2007, 114:253-262.

114. Munch IC, Ek J, Kessel L, Sander S, Almind GJ, Brøndum-Nielsen K, Linneberg A, Larsen M: Small hard macular drusen and peripheral drusen: Associations with AMD Genotypes in the Inter99 Eye Study. Invest Ophthalmol Vis Sci 2010, 51:2317-2321.

115. Subramanian A, Tamayo P, Mootha VK, Mukherjee S, Ebert BL, Gillette MA, Paulovich A, Pomeroy SL, Golub TR, Lander ES, Mesirov JP: Gene set enrichment analysis: a knowledge-based approach for interpreting genome-wide expression profiles. Proc Natl Acad Sci USA 2005, 102:15545-15550.

116. Chowers I, Gunatilaka TL, Farkas RH, Qian J, Hackam AS, Duh E, Kageyama M, Wang C, Vora A, Campochiaro PA, Zack DJ: Identification of novel genes preferentially expressed in the retina using a custom human retina cDNA microarray. Invest Ophthalmol Vis Sci 2003, 44:3732-3741.

117. Day A, Carlson MR, Dong J, O'Connor BD, Nelson SF: Celsius: a community resource for Affymetrix microarray data. Genome Biol 2007, 8:R112.

118. Müller M, Carter S, Hofer MJ, Campbell IL: Review: The chemokine receptor CXCR3 and its ligands CXCL9, CXCL10 and CXCL11 in neuroimmunity - a tale of conflict and conundrum. Neuropathol Appl Neurobiol 2010, 36:368-387.

119. Segal E, Friedman N, Koller D, Regev A: A module map showing conditional activity of expression modules in cancer. Nat Genet 2004, 36:1090-1098.

120. Gerlini G, Hefti HP, Kleinhans M, Nickoloff BJ, Burg G, Nestle FO: Cd1d is expressed on dermal dendritic cells and monocyte-derived dendritic cells. J Invest Dermatol 2001, 117:576-582.

121. Caux C, Vanbervliet B, Massacrier C, Azuma M, Okumura K, Lanier LL, Banchereau J: B70/B7-2 is identical to CD86 and is the major functional ligand for CD28 expressed on human dendritic cells. J Exp Med 1994, 180:1841-1847.

122. Maeda A, Crabb JW, Palczewski K: Microsomal glutathione S-transferase 1 in the retinal pigment epithelium: protection against oxidative stress and a potential role in aging. Biochemistry 2005, 44:480-489.

123. Dunaief $J$, Dentchev T, Ying GS, Milam AH: The role of apoptosis in agerelated macular degeneration. Arch Ophthalmol 2002, 120:1435-1442.

124. Johnson PT, Brown MN, Pulliam BC, Anderson DH, Johnson LV: Synaptic pathology, altered gene expression, and degeneration in photoreceptors impacted by drusen. Invest Ophthalmol Vis Sci 2005, 46:4788-4795.

125. Viola A, Luster AD: Chemokines and their receptors: Drug targets in immunity and inflammation. Annu Rev Pharmacol Toxicol 2008, 48:171-197.

126. Shi G, Maminishkis A, Banzon T, Jalickee S, Li R, Hammer J, Miller SS: Control of chemokine gradients by the retinal pigment epithelium. Invest Ophthalmol Vis Sci 2008, 49:4620-4630

127. Sancho D, Gómez M, Sánchez-Madrid F: CD69 is an immunoregulatory molecule induced following activation. Trends Immunol 2005, 26:136-140.

128. Yasuda Y, Li Z, Greenbaum D, Bogyo M, Weber E, Brömme D: Cathepsin V, a novel and potent elastolytic activity expressed in activated macrophages. J Biol Chem 2004, 279:36761-36770.
129. Johnson LV, Ozaki S, Staples MK, Erickson PA, Anderson DH: A potential role for immune complex pathogenesis in drusen formation. Exp Eye Res 2000, 70:441-449.

130. Gu X, Meer SG, Miyagi M, Rayborn ME, Hollyfield JG, Crabb JW, Salomon RG: Carboxyethylpyrrole protein adducts and autoantibodies, biomarkers for age-related macular degeneration. J Biol Chem 2003, 278:42027-42035.

131. Penfold PL, Provis JM, Furby JH, Gatenby PA, Billson FA: Autoantibodies to retinal astrocytes associated with age-related macular degeneration. Graefes Arch Clin Exp Ophthalmol 1990, 228:270-274.

132. Patel N, Ohbayashi M, Nugent AK, Ramchand K, Toda M, Chau KY, Bunce C, Webster A, Bird AC, Ono SJ, Chong V: Circulating anti-retinal antibodies as immune markers in age-related macular degeneration. Immunology 2005, 115:422-430.

133. Joachim SC, Bruns K, Lackner KJ, Pfeiffer N, Grus FH: Analysis of IgG antibody patterns against retinal antigens and antibodies to a-crystallin, GFAP, and a-enolase in sera of patients with "wet" age-related macular degeneration. Graefes Arch Clin Exp Ophthalmol 2007, 245:619-626.

134. Olson JK, Girvin AM, Miller SD: Direct activation of innate and antigenpresenting functions of microglia following infection with Theiler's virus. J Virol 2001, 75:9780-9789.

135. Combadière C, Feumi C, Raoul W, Keller N, Rodéro M, Pézard A, Lavalette S, Houssier M, Jonet L, Picard E, Debré P, Sirinyan M, Deterre P, Ferroukhi T, Cohen SY, Chauvaud D, Jeanny JC, Chemtob S, Behar-Cohen F, Sennlaub F: CX3CR1-dependent subretinal microglia cell accumulation is associated with cardinal features of age-related macular degeneration. J Clin Invest 2007, 117:2920-2928

136. Collier RJ, Wang Y, Smith SS, Martin E, Ornberg R, Rhoades K, Romano C: Complement deposition and microglial activation in the outer retina in light-induced retinopathy: inhibition by a $5-\mathrm{HT} 1 \mathrm{~A}$ agonist. Invest Ophthalmol Vis Sci 2011, 52:8108-8116.

137. Rutar M, Natoli R, Kozulin P, Valter K, Gatenby P, Provis JM: Analysis of complement expression in light-induced retinal degeneration: synthesis and deposition of C3 microglia/macrophages is associated with focal photoreceptor degeneration. Invest Ophthalmol Vis Sci 2011, 52:5347-5358.

138. Chao W, D'Amore PA: IGF2: epigenetic regulation and role in development and disease. Cytokine Growth Factor Rev 2008, 19:111-120.

139. Chen CC, Lau LF: Functions and mechanisms of action of CCN matricellular proteins. Int J Biochem Cell Biol 2009, 41:771-783.

140. Fedarko NS, Fohr B, Robey PG, Young MF, Fisher LW: Factor H binding to bone sialoprotein and osteopontin enables tumor cell evasion of complement-mediated attack. J Biol Chem 2000, 275:16666-16672.

141. Shijubo N, Uede T, Kon S, Nagata M, Abe S: Vascular endothelial growth factor and osteopontin in tumor biology. Crit Rev Oncog 2000, 11:135-146.

142. Wang ZY, Shen L, Tu L, Hu DN, Liu GY, Zhou ZL, Lin Y, Chen LH, Qu J: Erythropoietin protects retinal pigment epithelial cells from oxidative damage. Free Radic Biol Med 2009, 46:1032-1041.

143. Leung KW, Barnstable CJ, Tombran-Tink J: Bacterial endotoxin activates retinal pigment epithelial cells and induces their degeneration through IL-6 an IL-8 autocrine signaling. Mol Immunol 2009, 46:1374-1386.

\section{doi:10.1186/PREACCEPT-1418491035586234}

Cite this article as: Newman et al:: Systems-level analysis of age-related macular degeneration reveals global biomarkers and phenotypespecific functional networks. Genome Medicine 2012 4:16.

\section{Submit your next manuscript to BioMed Central and take full advantage of:}

- Convenient online submission

- Thorough peer review

- No space constraints or color figure charges

- Immediate publication on acceptance

- Inclusion in PubMed, CAS, Scopus and Google Scholar

- Research which is freely available for redistribution

Submit your manuscript at www.biomedcentral.com/submit
C Biomed Central 